\title{
Öğretmenlerin Mesleklerine Yönelik Tutumlarını Yordayan Değişkenlerin CHAID Analizi ile İncelenmesi
}

Neşe Dokumacı Sütçüi1

Type/Tür:

Research/Araştırma

Received/Geliş Tarihi: August

5/ 5 Ağustos 2020

Accepted/Kabul Tarihi:

November 13/ 13 Kasim 2020

Page numbers/Sayfa No: 799-824

Corresponding

Author/İletişimden Sorumlu

Yazar: ndokumaci@dicle.edu.tr

\section{$\checkmark$ iThenticate}

This paper was checked for plagiarism using iThenticate during the preview process and before publication. / Bu çalışma ön inceleme sürecinde ve yayımlanmadan önce iThenticate yazılımı ile taranmıştır.

Copyright $(\subset) 2017$ by Cumhuriyet University, Faculty of Education. All rights reserved.
Behçet Oral ${ }^{2}$

\section{Öz}

$\mathrm{Bu}$ araştırmada, öğretmenlerin mesleklerine yönelik tutumları üzerinde anlamlı etkisi olan bağımsız değişkenlerin belirlenmesi ve önem sırasının ortaya konulması amaçlanmıştır. Değişkenler arasındaki ilişkinin incelenmesi nedeniyle bu çalışma, ilişkisel (korelasyonel) bir araştırma niteliğindedir. Bu araştırma; 2018-2019 eğitim-öğretim yılı güz döneminde, Diyarbakır il merkezinde görev yapan 515 öğretmen ile gerçekleştirilmiştir. Veriler; "Kişisel Bilgi Formu" ve "Öğretmenlik Mesleğine Yönelik Tutum Ölçeği" ile toplanmıştır. Ölçek; 32 maddeden ve üç boyuttan oluşmaktadır. Verilerin analizinde; betimsel istatistikler, İki Aşamalı Kümeleme Analizi ve CHAID Analizi kullanılmıştır. Yapılan analizler neticesinde; öğretmenlik mesleğine yönelik tutum ölçeğinin alt boyutlarından olan sevgi, tatmin ve değer boyutları üzerinde öğretmenlerin çoğunluğunun olumlu tutuma sahip olduğu tespit edilmiştir. Sevgi, tatmin ve değer boyutları üzerinde etki düzeyi en yüksek olan yordayıcı değişken, "çalışılan kuruma hissedilen bağl1lık düzeyi"dir. Öğretmenlerin büyük bir kısmı çalıştıkları kuruma, çok ve orta düzeyde bağlı olan öğretmenlerden oluşmaktadır. Çalıştıkları kuruma yüksek düzeyde bağlı olan öğretmenler, düşük düzeyde bağlı olan öğretmenlere göre daha olumlu tutuma sahiptirler. Sevgi boyutu üzerinde anlamlı etkisi olan diğer yordayıcı değişkenler sırasıyla "maaşı yeterli bulup bulmama durumu", "cinsiyet", "okulların sosyoekonomik düzeyleri"; tatmin boyutu üzerinde anlamlı etkisi olan diğer yordayıcı değişkenler "kıdem", "maaşı yeterli bulup bulmama durumu", "öğrenim durumu", "cinsiyet"; değer boyutu üzerinde anlamlı etkisi olan diğer yordayıcı değişkenler ise "okulların sosyoekonomik düzeyleri", "cinsiyet" ve "öğrenim durumu"dur.

Anahtar Kelimeler: Tutum, öğretmenlik mesleği, iki aşamalı kümeleme analizi, CHAID analizi, kurumsal bağlılık

\section{Suggested APA Citation/Önerilen APA Atıf Biçimi:}

Dokumacı Sütçü, N., \& Oral, B. (2021). Öğretmenlerin mesleklerine yönelik tutumlarını yordayan değişkenlerin CHAID analizi ile incelenmesi. Cumhuriyet International Journal of Education, 10(2), 799-824. http://dx.doi.org/10.30703/cije.777377

\footnotetext{
${ }^{1}$ Dr., Dicle Üniversitesi Eğitim Fakültesi, Matematik ve Fen Bilimleri Eğitimi Bölümü, Diyarbakır/Türkiye Dr., Dicle University Faculty of Education, Department of Mathematics And Science Teaching, Diyarbakir/Turkey e-mail: $\underline{\text { ndokumaci@dicle.edu.tr }}$ ORCID ID: orcid.org/0000-0003-3279-4194

2 Prof. Dr, Dicle Üniversitesi Eğitim Fakültesi, Eğitim Bilimleri Bölümü, Diyarbakır/Türkiye Prof. Dr., Dicle University Faculty of Education, Department of Educational Sciences, Diyarbakir/Turkey e-mail: oralbehcet@dicle.edu.tr ORCID ID: orcid.org/0000-0002-6885-1683
} 


\title{
Examination of the Variables that Predict the Attitudes of Teachers towards Their Profession Using the CHAID Analysis
}

\begin{abstract}
In this study, it was aimed to determine the independent variables that have a significant effect on the attitudes of teachers towards their profession and to reveal the order of importance of these variables. This is a relational (correlational) research since the relationship between the variables has been examined. The research was carried out with a total of 515 teachers working in Diyarbakır provincial center during the fall semester of the 2018-2019 academic year. "Personal Information Form" and "the Attitudes towards Teaching Profession Scale" were applied to the teachers who participated in the study. The scale consists of 32 items and three dimensions. Descriptive statistics, Two-Stage Clustering Analysis and CHAID Analysis were used to analyse the data collected. The majority of the teachers have a positive attitude towards the love, satisfaction and value sub-dimensions of the attitudes towards teaching profession scale. The predictor variable with the highest effect on the dimensions of love, satisfaction and value was found to be "the level of attachment felt towards the institution". The majority of the teachers are either highly or moderately attached to their institutions they are working for. Teachers, who are highly attached to their institutions, have a more positive attitude compared to those who have a low level of attachment. Other predictive variables with a significant effect on the dimension of love are "whether they are satisfied with the salary", "gender", "socioeconomic levels of schools"; the other predictive variables that have a significant effect on the dimension of satisfaction are "seniority", "whether they are satisfied with the salary", "educational background", "gender"; and the other predictive variables that have a significant effect on the dimension of "value" are, "socioeconomic levels of schools", "gender" and "educational background".
\end{abstract}

Keywords: Attitude, teaching profession, two-stage clustering analysis, CHAID analysis, organizational commitment

\section{Giriş}

Toplumların içinde bulundukları çağın gerektirdiği bilgi, beceri ve donanıma sahip olup ileri medeniyetler seviyesine ulaşabilmesi, bilgi çağını yaşayıp bilgi toplumu olabilmesi (Akgün ve Özgür, 2014) ancak eleştirel, yaratıcı, analitik düşünen, karşılaştığı problemlere birden fazla çözüm yolu üretebilen, yenilik ve değişimlere ayak uydurabilen, araştırmacı, bilgiyi üreten ve yöneten bireyler yetiştirmeleri ile mümkündür. Hızlı değişme ve gelişmelere uyum sağlayıp katkı sunabilen bireylerin yetiştirilmesinde, eğitim sistemlerinin önemi büyüktür (Kültekin, 2006). Eğitim sistemleri, yetiştireceği insan gücünde olmasını istediği özellikleri; eğitim felsefesi, eğitim politikası ve sahip olduğu insan gücü 1şığında toplumun ve bireyin ihtiyaçlarını da dikkate alarak düzenler. Bu süreçte en önemli görev kuşkusuz öğretmenlere düşmektedir (Durmuşoğlu, Yanık ve Akkoyunlu, 2009). Çünkü öğretmenler; toplumun gereksinim duyduğu tüm mesleklere insan gücü yetiştirerek ulusun geleceğini şekillendirmiş dolayısıyla toplumun en önemli görevlerinden birini yerine getirmiş olurlar (Aynal Kilimci, 2011). Bu bağlamda, eğitim sistemlerinin başarısının öğretmenlerinin nitelikleri ve yeterlikleriyle doğru orantılı olduğu söylenebilir (Şahin ve Şahin, 2017). Bu bağlamda öğrencilere uygun eğitimi sağlamak için profesyonel öğretmenlerin yetiştirilmesi esastır (Alkhateeb, 2013).

Öğrenciler için önemli rol model olan öğretmenlerin (Stiegelbauer, 1992) temel görevi; eğitimin amaçları doğrultusunda öğrencilerde istendik yönde, kalıcı izli davranış değişikliği meydana getirmektir (Erden, 1995). Öğrenme, öğrencinin 
zihninde devam eden aktif bir süreçtir ve öğretmenin görevi ise bu süreci kolaylaştırmaktır (Dashputra, Chari, Badwaik ve Sidddique, 2019). Öğretmenler, öğrencilerin tutumlarını, alışkanlıklarını, davranışlarını ve her şeyden önce karakter ve kişiliklerini şekillendirmede önemli bir rol oynarlar (Aggarwal, 2010). Öğretmenler, öğrencilerin davranışlarını daha iyi yaşama katkıda bulunan arzu edilen değişiklikleri yapmaları için etkilemektir (Odike ve Nnaekwe, 2018). Öğretmenin bunları yerine getirebilmesi için gerekli konu alanı bilgisine, öğretmenlik meslek bilgisine ve genel kültür ve yetenek bilgisine sahip olması gerekir. Bu alanlarla ilgili davranışların birinden yoksun olan öğretmenlerden, istenilen verimi ve başarıyı elde etmek oldukça güçtür (Erden, 1995). Öğretmenlik aynı zamanda özverili, sabırlı, hoşgörülü, anlayışlı, tutarlı, uyumlu, güler yüzlü, yardımsever, adil olmayı ve mesleği severek yerine getirmeyi gerektirir (Dokumacı Sütçü ve Oral, 2019). Dolayısıyla, öğretmenlerin öğrenci başarılarına olumlu katkı sağlayacak bilgi, beceri, tutum ve davranışlara sahip olmaları gerekir (Özkan, 2012). Örgütsel davranış kapsamında, bir sınıf ortamında olması gereken öğretmen davranışlarını belirleyen değişkenler incelendiğinde, bu değişkenlerden en önemlilerinden birinin öğretmenlerin mesleklerine karşı tutumları olduğu görülmektedir (Üstüner, 2006).

Tutum, insanlar, gruplar, sosyal sorunlar veya daha genel olarak çevredeki herhangi bir olay ile ilgili olarak organize ve tutarl bir duygu ve tepki biçimidir (Zarzolawmi, 2019). Bireyin, herhangi bir durum, olay veya nesneye karşı sahip olduğu tepki, eğilimidir (Temizkan, 2008). Başka bir ifadeyle bireyin; psikolojik olarak bir objeye, kişiye, duruma vb. ilişkin davranış, düşünce ve duygularına yön verme, bunların yanında ya da karşısında olma durumudur (Semerci ve Semerci, 2004). Tutum, insanların belirli bir duruma karşı tepkilerini belirlemede önemli bir rol oynar (Al-Zaidiyeen, Lai Mei ve Fook, 2010). Dolayısıyla bir bireyin bir uyarana karşı tutumu, o bireyin ilgili uyarana karşı davranışını etkiler. Mesleki eğitim, bireyleri mesleğe hazırlama amacıyla verilen bir eğitimdir. Bu eğitimde, mesleği seçen ve o meslek doğrultusunda eğitim alan kişilere gelecekte o mesleğe özgü davranışları gösterebilmesi için gerekli olan bilgi, beceri ve tutumlar kazandırılmaya çalışılır. Bu durum öğretmenlik mesleğinde son derece önemlidir (Üstüner, 2006). Öğretmenlik mesleğinin gerekliliklerini yerine getirmede, bu mesleğe yönelik tutumlar büyük önem taşımaktadır (Durmuşoğlu, Yanık ve Akkoyunlu, 2009). Öğretmenlik mesleğine yönelik tutum; bireyin öğretmenlik mesleği hakkındaki düşünceleri, duyguları, bu mesleğe karşı hissettikleri ve bu mesleği icra ederken ortaya koydukları performans şeklinde tanımlanabilir (Camadan ve Duysak, 2010). Yüksek motivasyona sahip ve mesleğine karşı olumlu tutuma sahip öğretmenler öğrencilerine karşı iyi bir ilişki kurabilirler. Dolayısıyla sabır, özveri ve sürekli çalışma gerektiren öğretmenlik mesleğinde başarılı olabilmek için bu mesleği sevmek ve isteyerek yapmak önemlidir (Brown, 2001). Dolayısıyla öğretmenlerin mesleklerine yönelik tutumlarını bilmek, mesleklerindeki başarıyı ve doyumu yordamaya imkân verecektir (Erkuş, Sanlı, Bağlı ve Güven, 2000). Mesleklerine yönelik olumlu tutumlara sahip olan öğretmenler; araştırmacı olurlar, değişim ve yenilikleri takip ederler, öğrencileri motive ederler, öğrencilere karşı samimi, adil, hoşgörülü, sabırlı, tutarlı davranırlar, katı kuralcı olmazlar, zamanlarını etkili bir şekilde yönetirler, görevlerini eksiksiz yerine getirirler. Kısacası bu tutumlara sahip öğretmenler, mesleklerini severek yaparlar (Çeliköz ve 
Çetin, 2004). Dolayısıyla eğitim sisteminde, bireylerin meslek seçiminde sahip olduğu özellikler ve seçtikleri mesleğe yönelik tutumlarının önemli rol oynadığı söylenebilir.

Öğretmenlerin rollerini nasıl hissettikleri ve algıladıkları, bu rolde nasıl davrandıkları, öğrencilerle olan etkileşimlerine yansır (Saks, Soosaar ve Ilves, 2016). Öğrenciler açısından etkili ve verimli öğrenme ancak olumlu tutuma sahip öğretmenler tarafından sağlanabilir. Bu nedenle öğretmenlerin mesleklerine yönelik tutumu, öğrencilerin öğrenmesi için önemli bir değişkendir (Pancholi ve Bharwad, 2015). Öğretmenin entelektüel tutumları, duygusal tepkileri, çeşitli alışkanlıkları ve kişilikleri öğrencilerini akademik başarı, kişilik, ilgi vb. yönlerden etkilemektedir (Odike ve Nnaekwe, 2018). O halde öğretmenlerin mesleklerine yönelik olumlu tutumlarını artıracak tedbirlerin alınması gerekmektedir. Öğretmenler mesleklerine karşı olumlu bir tutum geliştirirlerse, öğrencilerinin öğrenmeye yönelik içsel motivasyonunu kolayca geliştirebilirler, öğrencileri ile daha verimli bir iletişim kurabilirler ve öğrenme durumlarının çeşitlendirilmesine ve kişiselleştirilmesine daha fazla katkıda bulunabilirler (Zarzolawmi, 2019). Böylelikle öğrenciler için etkili ve verimli öğrenme, ancak arzu edilen tutuma sahip öğretmenler tarafından sağlanabilir (Kumar, 2016) .

İlgili alanyazında, öğretmenlik mesleğine yönelik tutum ile ilgili yapılan araştırmalar incelendiğinde; öğretmen adaylarının öğretmenlik mesleğine yönelik tutumları çoğunlukla araştırılmasına rağmen öğretmenlerin mesleki tutumlarını belirlemeye yönelik sınırlı sayıda araştırma (Doğan, 2013; Güloğlu Demir, 2016; Kaysi ve Gürol, 2016; Korkmaz ve Sadık, 2011; Özyürek ve Erbay, 2015; Piji Küçük, 2012; Polat, Arslan ve Satıc1, 2016) olduğu görülmüştür. Oral, Dokumacı Sütçü ve Yazar (2019) tarafından Türkiye'de öğretmenlik mesleğine yönelik tutum ile ilgili yapılan makaleleri incelemek amacıyla yapılmış olan bir araştırmada da öğretmenlik mesleğine yönelik tutum ile ilgili makalelerde genellikle eğitim fakültesinde ve pedagojik formasyon programında öğrenim gören öğretmen adayları ile çalışıldığı; öğretmenlerin mesleki tutumlarının ise çok az sayıda çalışıldığı tespit edilmiştir. Bununla birlikte yapılan alanyazın taramasında öğretmenlerin mesleklerine yönelik tutumlarını yordayan değişkenlerin, CHAID analizi ile incelendiği herhangi bir araştırmaya rastlanmamıştır. Bu nedenle bu araştırmada, öğretmenlerin mesleklerine yönelik tutumları üzerinde anlamlı etkisi olan bağımsız değişkenlerin belirlenmesi ve önem sırasının ortaya konulması amaçlanmıştır.

\section{Araştırma Modeli}

\section{Yöntem}

Değişkenler arasındaki ilişkinin incelenmesi amacıyla yapılan bu çalışma, ilişkisel (korelasyonel) bir araştırma niteliğindedir. İlişkisel araştırma; iki veya daha çok sayıdaki değişken arasında birlikte değişimin varlığını ve derecesini belirleyen araştırma desenleridir (Karasar, 2011).

\section{Çalışma Grubu}

Araştırma, 2018-2019 eğitim-öğretim yılı bahar dönemi Diyarbakır il merkezinde görev yapan 515 öğretmen ile gerçekleştirilmiştir. Veri toplama aracı; 537 öğretmene uygulanmış olup eksik, yanlış veya özensiz doldurulan 22 veri toplama aracı değerlendirmeye alınmamıştır. Araştırmanın katılımcıları hakkındaki genel bilgilere, Tablo 1'de yer verilmiştir. 
Tablo 1.

Araştırmanın Katılımcıları Hakkındaki Genel Bilgiler

\begin{tabular}{|c|c|c|c|}
\hline Değişkenler & & Frekans & Yüzde \\
\hline \multirow{2}{*}{ Cinsiyet } & Erkek & 239 & 46.4 \\
\hline & Kadın & 276 & 53.6 \\
\hline \multirow{5}{*}{ Kıdem } & $1-5$ & 102 & 19.8 \\
\hline & $6-10$ & 92 & 17.9 \\
\hline & $11-15$ & 127 & 24.7 \\
\hline & $16-20$ & 93 & 18.1 \\
\hline & 21 ve üzeri & 101 & 19.6 \\
\hline \multirow{4}{*}{ Öğrenim Durumu } & Lisans & 464 & 90.1 \\
\hline & Tezsiz Yüksek lisans & 33 & 6.4 \\
\hline & Tezli Yüksek lisans & 16 & 3.1 \\
\hline & Doktora & 2 & 0.4 \\
\hline \multirow{3}{*}{ Okul türü } & İlkokul & 193 & 37.5 \\
\hline & Ortaokul & 202 & 39.2 \\
\hline & Lise & 120 & 23.3 \\
\hline \multirow{3}{*}{$\begin{array}{l}\text { Okulların sosyoekonomik } \\
\text { düzeyleri }\end{array}$} & Düşük & 183 & 35.5 \\
\hline & Orta & 283 & 55.0 \\
\hline & Yüksek & 49 & 9.5 \\
\hline \multirow{3}{*}{ Medeni durum } & Evli & 397 & 77.1 \\
\hline & Bekâr & 111 & 21.6 \\
\hline & Boşanmış & 7 & 1.4 \\
\hline \multirow{3}{*}{$\begin{array}{l}\text { Maaşı yeterli bulup bulmama } \\
\text { durumu }\end{array}$} & Evet & 28 & 5.4 \\
\hline & Hayır & 401 & 77.9 \\
\hline & Kismen & 86 & 16.7 \\
\hline \multirow{5}{*}{$\begin{array}{l}\text { Çalışılan kuruma hissedilen } \\
\text { bağll1ık düzeyi }\end{array}$} & Çok & 207 & 40.2 \\
\hline & Orta & 246 & 47.8 \\
\hline & $\mathrm{Az}$ & 42 & 8.2 \\
\hline & Hiç & 20 & 3.9 \\
\hline & Toplam & 515 & 100 \\
\hline
\end{tabular}

\section{Veri Toplama Araçları}

Araştırmaya katılan öğretmenlere "Kişisel Bilgi Formu” ve “Öğretmenlik Mesleğine Yönelik Tutum Ölçeği" uygulanmıştır.

Kişisel bilgi formu. Bu formda, öğretmenlerin; cinsiyetlerine, kıdemlerine, öğrenim durumlarına, görev yaptıkları okulların türlerine, görev yaptıkları okulların sosyoekonomik düzeylerine, medeni durumlarına, aldıkları maaşı yeterli bulup bulmama durumlarına, çalıştıkları kuruma hissettikleri bağlılık düzeylerine ilişkin sorular yer almaktadir.

Öğretmenlik mesleğine yönelik tutum ölçeği. Bu ölçek, Çetin (2003) tarafından öğretmen adayları için geliştirilmiş; Güloğlu Demir (2016) tarafından öğretmenlere uyarlanmıştır. 5'li Likert tipi şeklinde hazırlanan ölçekte yer alan derecelendirme ifadeleri "Hiç Katılmıyorum", "Biraz Katılıyorum”, “Orta Düzeyde Katılıyorum”, “Büyük Ölçüde Katılıyorum”, “Tamamen Katılıyorum” şeklindedir. Bu derecelendirme ifadeleri olumlu maddeler için sırasıyla 1, 2, 3, 4, 5 şeklinde, olumsuz maddeler ise 5, 4, 3, 2, 1 şeklinde puanlanmıştır. 35 madde ve üç faktörden oluşan ölçeğin bir maddesi öğretmenler için uygun olmadığından ölçekten çıkarılmış, geriye kalan 34 maddelik ölçeği, öğretmenlere uyarlamak amacıyla yapılan geçerlik ve güvenirlik çalışmaları 333 öğretmen ile gerçekleştirilmiştir. Faktör analizi sonucunda 
faktör yükü düşük olan iki madde ölçekten çıkarıldıktan sonra kalan 32 maddenin, öğretmenlerin mesleklerine yönelik tutumlarına ilişkin 10 maddeden oluşan "Sevgi", 14 maddeden oluşan "Tatmin" ve 8 maddeden oluşan “Değer" olmak üzere üç yapıyı ölçtügü belirlenmiştir. Ölçeğin güvenirliğini belirlemek amacıyla Cronbach Alfa katsayıları hesaplanmış ve ölçeğin geneli için .93 olarak bulunmuştur. Sevgi boyutu için .92; tatmin boyutu için 90 ve değer boyutu için .81'dir.

$\mathrm{Bu}$ araştırma kapsamında, ölçümlerin güvenirliği Cronbach Alfa yöntemiyle yeniden hesaplanmış ve ölçeğin geneli için .94 olarak bulunmuştur. Sevgi boyutu için .93; tatmin boyutu için .87 ve değer boyutu için .83'tür. Büyüköztürk (2011)'e göre; elde edilen değerler .70 ve üzeri olduğu için ölçme sonuçlarının güvenilir olduğu söylenebilir.

\section{Verilerin Analizi}

Öğretmenlerden elde edilen verilere; “SPSS Clementine 12.0” programı kullanılarak betimsel istatistikler, İki Aşamalı Kümeleme Analizi ve CHAID analizi uygulanmıştır.

İki aşamalı kümeleme analizi. Heterojen olan veri setini homojen alt kümelere bölmeyi ve elde edilen toplam sürekli puanları kategorik puanlara dönüştürmeyi hedef almaktadır (Kayri, 2007). Böylelikle uygun, işe yarar ve özetleyici bilgiler elde etmede, araştırmacıya yardımcı olmaktır (Harrigan, 1985; Akt: Kayri, Elkonca, Şevgin ve Ceyhan, 2014).

CHAID (Chi-squared Automatic Interaction Detection) analizi. Birçok doğrusal regresyonda kullanılan bir sınıflandırma ağacı tekniği olan CHAID analizi (Althuwaynee, Pradhan ve Ahmad, 2014), büyük dalların yukarıdan aşağıya doğru azalacak şekilde daha küçük dallara bölünmesi işlemidir (Amalita, Kurniawati ve Fitria, 2019). Bu analiz, yordanan (bağımlı) değişkende en fazla farklılaşmayı gösteren yordayıcı (bağımsız) değişkenlerin kapsamlı bir şekilde araştırılması yoluyla bu değişkenler arasındaki en güçlü ilişkiyi saptamak için sistematik bir algoritma kullanmaktadır (Chan, Cheing, Chan, Rosenthal ve Chronister, 2006). Bağımlı değişkenle ilişkili bağımsız değişkenlerin hiyerarşik düzende bir sıralaması yapmakta ve sinıflama yöntemi kullanarak her bir aşamada örneklem olabilecek homojen alt gruplara indirgeme yapmaktadır. CHAID analizinde, ilk aşamada yapılan aşamalı regresyon analizi neticesinde bağımlı değişken ile en çok ilişkili olan bağımsız değişkenler, düğümler oluşturmaktadır. CHAID analizindeki karar ağacının altında oluşan düğümler, değişkenlerin önem sırasını belirlemektedir (Kayri ve Boysan, 2007).

CHAID analizinde kullanılan istatistiksel testin seçimi, bağımlı değişkenin sürekli ya da kategorik olma durumuna göre $F$ testi $(F)$ ya da ki-kare testi $\left(\chi^{2}\right)$ olabilmektedir. CHAID analizi; sürekli ve kategorik veriler üzerinde çalışması, geniş örneklemlerde kullanımının uygun olması, potansiyel olarak çok güvenilir tahminler sunabilmesi, parametrik ve parametrik olmayan ayrımını ortadan kaldırmasından dolayı yarı parametrik özellik taşımaktadır (Atasoy ve Güçlü, 2020). CHAID analizi, birçok alanda kullanım olanağı sağlayan karar ağaçlarından biridir (Atieh vd., 2019). Aynı zamanda eğitim bilimleri ile ilgili araştırmalar için de verimli bir şekilde kullanılabilmektedir (Kayri ve Boysan, 2007).

$\mathrm{Bu}$ araştırmada, CHAID analizinin doğası gereği, parametrik testlerin varsayımlarını gerektirmediği için değişkenler doğrudan analiz edilmiştir. Kurulan modelde yordanan (bağımlı) değişken öğretmenlik mesleğine yönelik tutum ölçeğinin 
alt boyutları olan "sevgi", "tatmin" ve "değer" boyutlarından elde edilmiş toplam puanların kategorik hali (olumlu-orta/eşik-olumsuz); yordayıcı (bağımsız) değişkenler ise öğretmenlerin cinsiyetleri, kıdemleri, öğrenim durumları, medeni durumları, görev yaptıkları okulların türleri, okullarının sosyoekonomik düzeyleri, aldıkları maaşı yeterli bulup bulmama durumları ve çalıştıkları kuruma hissettikleri bağlılık düzeyleridir. CHAID analizinde, anlamlı olan yordayıcı değişkenler karar ağacı dallanma sürecindeki düğümlerden görülebilir. Ăgacin düğümlerinde yukarıdan aşağıya görünen değişkenler, sırasıyla değişkenin önem sırası hakkında bilgi sağlamaktadır.

\section{Araştırmanın Etik İzinleri}

Yapılan bu çalışmada "Yükseköğretim Kurumları Bilimsel Araştırma ve Yayın Etiği Yönergesi" kapsamında uyulması belirtilen tüm kurallara uyulmuştur. Yönergenin ikinci bölümü olan "Bilimsel Araştırma ve Yayın Etiğine Aykırı Eylemler” başlığı altında belirtilen eylemlerden hiçbiri gerçekleştirilmemiştir.

Etik kurul izin bilgileri

Etik değerlendirmeyi yapan kurul adı = Dicle Üniversitesi Rektörlüğü Eğitim Bilimleri Etik Kurulu

Etik değerlendirme kararının tarihi $=28 / 01 / 2019$

Etik değerlendirme belgesi sayı numarası $=90871155-044-$

\section{Bulgular}

Öğretmenlik mesleğine yönelik tutum ölçeğinin "sevgi", "değer" ve "tatmin" boyutlarından elde edilen puanlar İki Aşamalı Kümeleme Analizi ile olumlu, orta düzey ve olumsuz olmak üzere homojen ve kategorik olarak üç kümeye ayrılmıştır. 1 . Küme her bir boyuta ilişkin olumlu ifadelere sahip olan öğretmenlerden, 2. Küme her bir boyuta ilişkin orta düzey olumlu ifadelere sahip olan öğretmenlerden, 3 . Küme ise her bir boyuta ilişkin olumsuz ifadelere sahip olan ögretmenlerden oluşmaktadır. Öğretmenlerin ölçeğin her bir boyutundan aldıkları puanlar homojen ve kategorik olarak üç küme üzerinden CHAID analizine dâhil edilmiştir.

Öğretmenlik mesleğine yönelik tutum ölçeğinin "sevgi” alt boyutuna ilişkin toplam puana ait İki Aşamalı Kümeleme Analizi sonuçları Tablo 2' de verilmiştir.

Tablo 2.

"Sevgi" boyutuna ilişkin toplam puana ait İki Aşamah Kümeleme Analizi sonuçlan

\begin{tabular}{lcccc}
\hline Kümeleme & $\mathrm{N}$ & $\overline{\mathrm{X}}$ & $\mathrm{SS}$ & $\%$ \\
\hline 1. Küme (Olumlu)-Sevgi 1 & 200 & 44.84 & 3.66 & 38.84 \\
2.Küme (Eşik/Orta düzey)-Sevgi 2 & 172 & 32.54 & 3.32 & 33.40 \\
3.Küme (Olumsuz)-Sevgi 3 & 143 & 19.83 & 4.42 & 27.77 \\
\hline
\end{tabular}

Tablo 2 incelendiğinde, birinci kümede (olumlu) 200 (\%38.84) öğretmen yer almakta ve toplam puan ortalamaları $44,84 \pm 3.66$ değerinde; ikinci kümede (eşik/orta düzey) 172 (\%33.40) öğretmen yer almakta ve toplam puan ortalamaları 32,54 \pm 3.32 değerinde ve üçüncü kümede (olumsuz) ise 143 (\%27.77) öğretmen yer almakta ve toplam puan ortalamaları 19,83 \pm 4.42 değerindedir. İkinci küme eşik değer olarak ele alınmış olup toplam puanı eşik değerin üstünde olan öğretmenlerin "sevgi" boyutuna 
ilişkin olumlu, eşik değerin altında puan alan öğretmenlerin ise olumsuz tutuma sahip oldukları söylenebilir.

Öğretmenlik mesleğine yönelik tutum ölçeğinin "sevgi" alt boyutuna ilişkin CHAID analizi ile elde edilen karar ağacı Şekil 1'de gösterilmiştir.

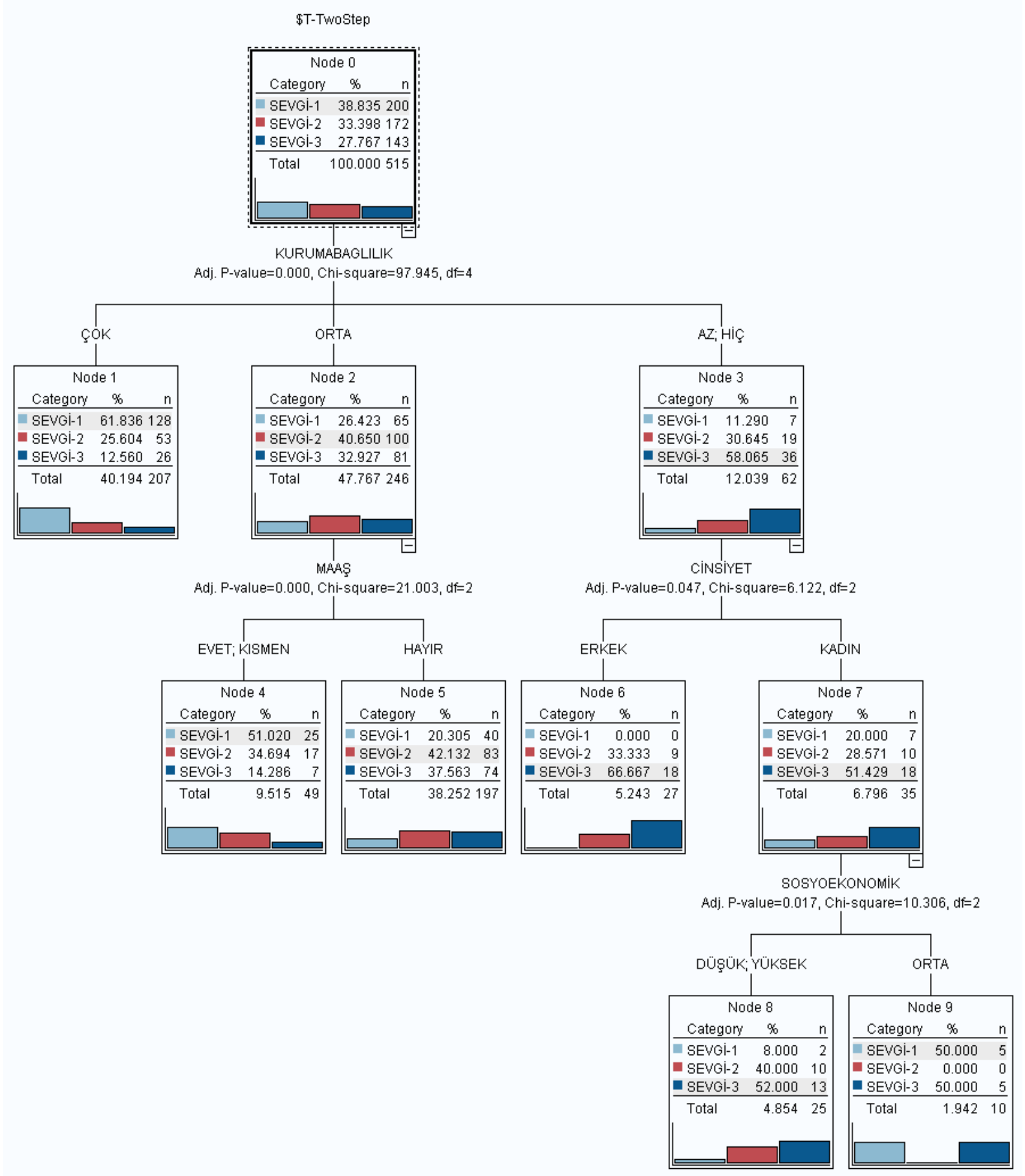

Şekil 1. "Sevgi" boyutuna ilişkin CHAID analizi ile elde edilen karar ağacı

Şekil 1'de görüldüğü üzere, CHAID analizi sonucuna göre "sevgi" boyutunu açıklayan 9 düğüm bulunmuştur. Bu boyutu en iyi açıklayan değişken "çalışılan 
kuruma hissedilen bağlılık düzeyi"dir $\left(\chi^{2}=97.945 ; p=0.000\right)$. Bu değişken bağımlı değişkeni üç gruba ayırmış olup, gruplar arasında anlamlı farklılıklar elde edilmiştir. Öğretmenlerin \%47.77'si görev yaptıkları kuruma orta düzeyde bağlı olan öğretmenlerden, \%40.19'u çok bağlı olan öğretmenlerden, \%12.04'ü ise az bağlı olan ya da hiç bağlı olmayan öğretmenlerden oluşmaktadır. Görev yaptıkları kuruma çok bağl1 olan öğretmenlerin \%61.84' ü sevgi boyutuna ilişkin olumlu tutuma; \%25.60'1 orta düzeyde tutuma; \%12.56'sı olumsuz tutuma sahiptirler. Görev yaptıkları kuruma orta düzeyde bağlı olan öğretmenlerin sevgi boyutuna ilişkin \%40.65'i orta düzeyde tutuma; \% 32.93'ü olumsuz tutuma; \%26.42'si olumlu tutuma sahiptirler. Görev yaptıkları kuruma az bağlı olan ya da hiç bağlı olmayan öğretmenlerin \%58.07'si sevgi boyutuna ilişkin olumsuz tutuma; \%30.65'i orta düzeyde tutuma; \% 11.29'u olumlu tutuma sahiptirler.

Görev yaptıkları kuruma orta düzeyde bağlı olan öğretmenlerin oluşturduğu kümeyi en iyi açıklayan değişken, "maaşı yeterli bulup bulmama durumu" dur $\left(\chi^{2}=\right.$ 21.003; $p=0.000)$. Bu değişken bağımlı değişkeni iki gruba ayırmış olup, gruplar arasında anlamlı farklılıklar elde edilmiştir. Görev yaptıkları kuruma orta düzeyde bağlı olan öğretmenlerin \%80.10 aldıkları maaşı yeterli bulmamakta; \%19.90'1 ise yeterli bulmaktadır. Görev yaptıkları kuruma orta düzeyde bağlı olan, aldıkları maaşı yeterli bulan öğretmenlerin sevgi boyutuna ilişkin \%51.02'si olumlu tutuma; \% 34.69'u orta düzeyde tutuma; \%14.29'u olumsuz tutuma sahiptirler. Görev yaptıkları kuruma orta düzeyde bağlı olan, aldıkları maaşı yeterli bulmayan öğretmenlerin sevgi boyutuna ilişkin \%42.13'ü orta düzeyde tutuma; \% 37.56's olumsuz tutuma; \%20.31'i olumlu tutuma sahiptirler.

Görev yaptıkları kuruma az bağlı olan ya da hiç bağlı olmayan öğretmenlerin oluşturduğu kümeyi en iyi açıklayan değişken "cinsiyet"tir $\left(\chi^{2}=6.122 ; p=0.047\right)$. Görev yaptıkları kuruma az bağlı olan ya da hiç bağlı olmayan öğretmenlerin \%56.45’i kadın öğretmenlerden oluşurken; \% 43.55'i erkek öğretmenlerden oluşmaktadır. Görev yaptıkları kuruma az bağlı olan ya da hiç bağlı olmayan, kadın öğretmenlerin \%51.43 gibi büyük çoğunluğu sevgi boyutuna ilişkin olumsuz tutuma; \% 28.57'si orta düzeyde tutuma; \%20.00'1 olumlu tutuma sahiptirler. Görev yaptıkları kuruma az bağlı olan ya da hiç bağlı olmayan, erkek öğretmenlerin \%66.67 gibi büyük çoğunluğu sevgi boyutuna ilişkin olumsuz tutuma; \% 33.33'ü orta düzeyde tutuma sahiptirler. Görev yaptıkları kuruma az bağlı olan ya da hiç bağlı olmayan erkek öğretmenlerin olumlu tutuma sahip olmadıkları gözlenmiştir.

Görev yaptıkları kuruma az bağlı olan ya da hiç bağlı olmayan kadın öğretmenlerin oluşturduğu kümeyi en iyi açıklayan değişken ise "okullarının sahip olduğu sosyoekonomik düzey" dir $\left(\chi^{2}=10.306 ; p=0.017\right)$. Bu değişken bağıml değişkeni iki gruba ayırmış olup, gruplar arasında anlamlı farklılıklar elde edilmiştir. Görev yaptıkları kuruma az bağlı olan ya da hiç bağlı olmayan kadın öğretmenlerin \%71.43'üne göre sosyoekonomik düzeyi yüksek ve düşük okullarda; \%28.57' sine göre sosyoekonomik düzeyi orta düzey olan okullarda görev yapmaktadırlar. Görev yaptıkları kuruma az bağlı olan ya da hiç bağlı olmayan kadın öğretmenlerden sosyoekonomik açıdan yüksek ve düşük düzey okullarda görev yaptıklarını belirtenlerin \%52.00'si sevgi boyutuna ilişkin olumsuz tutuma; \%40.00'1 orta düzeyde tutuma ve \%8.00'i olumlu tutuma sahiptirler. Görev yaptıkları kuruma az bağlı olan ya da hiç bağlı olmayan kadın öğretmenlerden sosyoekonomik açıdan orta düzeyde 
okullarda görev yaptıklarını belirtenlerin \%50.00'si sevgi boyutuna ilişkin olumlu tutuma; \% 50.00'si olumsuz tutuma sahiptirler.

Öğretmenlik mesleğine yönelik tutum ölçeğinin "tatmin” alt boyutuna ilişkin toplam puana ait İki Aşamalı Kümeleme Analizi sonuçlarına Tablo 3’te yer verilmiştir. Tablo 3.

"Tatmin" boyutuna ilişkin toplam puana ait İki Aşamalı Kümeleme Analizi sonuçları

\begin{tabular}{lcccc}
\hline Kümeleme & $\mathrm{N}$ & $\overline{\mathrm{X}}$ & $\mathrm{SS}$ & $\%$ \\
\hline 1.Küme (Olumlu)-Tatmin 1 & 252 & 63.70 & 3.91 & 48.93 \\
2.Küme (Eşik/Orta Düzey)-Tatmin 2 & 204 & 49.26 & 4.62 & 39.61 \\
3.Küme (Olumsuz)-Tatmin 3 & 59 & 33.03 & 6.58 & 11.46 \\
\hline
\end{tabular}

Tablo 3 incelendiğinde, birinci kümede (olumlu) 252 (\%48.93) öğretmen yer almakta ve toplam puan ortalamaları 63,70 \pm 3.91 değerinde; ikinci kümede (eşik/orta düzey) 204 (\%39.61) öğretmen yer almakta ve toplam puan ortalamaları $49.26 \pm 4.62$ değerinde ve üçüncü kümede (olumsuz) ise 59 (\%33.03) öğretmen yer almakta ve toplam puan ortalamaları 33,03 \pm 6.58 değerindedir. İkinci küme eşik değer olarak ele alınmış olup, toplam puanı eşik değerin üstünde olan öğretmenlerin "tatmin" boyutuna ilişkin olumlu tutuma, eşik değerin altında puan alan öğretmenlerin ise olumsuz tutuma sahip oldukları söylenebilir.

Öğretmenlik mesleğine yönelik tutum ölçeğinin "tatmin" alt boyutuna ilişkin CHAID analizi ile elde edilen karar ağacı Şekil 2'de gösterilmiştir.

Şekil 2'de görüldüğü üzere, CHAID analizi sonucuna göre "tatmin" boyutunu açıklayan 13 düğüm bulunmuştur. "Tatmin" boyutunu en iyi açılayan değişken "çalışılan kuruma hissedilen bağlılık düzeyi" dır $\left(\chi^{2}=98.925 ; p=0.000\right)$. Bu değişken bağımlı değişkeni üç gruba ayırmış olup, gruplar arasında anlamlı farklılıklar elde edilmiştir. Öğretmenlerin \%47.77'si görev yaptıkları kuruma orta düzeyde bağlı olan öğretmenlerden, \%40.19’u görev yaptıkları kuruma çok bağlı olan öğretmenlerden, \%12.04'ü ise az bağlı olan ya da hiç bağlı olmayan öğretmenlerden oluşmaktadır. Görev yaptıkları kuruma çok bağlı olan öğretmenlerin \%71.04'ü tatmin boyutuna ilişkin olumlu tutuma; \%26.09'u orta düzeyde tutuma; \% 3.00'ü olumsuz tutuma sahiptirler. Görev yaptıkları kuruma orta düzeyde bağlı olan öğretmenlerin tatmin boyutuna ilişkin \%49.59'u orta düzeyde tutuma; \% 37.81'i olumlu tutuma; \%12.60'1 olumsuz tutuma sahiptirler. Görev yaptıkları kuruma az bağlı olan ya da hiç bağlı olmayan öğretmenlerin \%45.16'sı tatmin boyutuna ilişkin orta düzeyde tutuma; \%35.48'i olumsuz tutuma; \% 19.36's olumlu tutuma sahiptirler.

Görev yaptıkları kuruma çok bağlı olan öğretmenlerin oluşturduğu kümeyi en iyi açıklayan değişken "kıdem" dir $\left(\chi^{2}=13.352 ; p=0.019\right)$. Bu değişken bağımlı değişkeni iki gruba ayırmış olup, gruplar arasında anlamlı farklılıklar elde edilmiştir. Görev yaptıkları kuruma çok bağlı olan öğretmenlerin \%56.04'ü 1-5, 6-10, 21 ve üzeri kıdeme sahip olan öğretmenlerden; \%43.96'sı ise 11-15 ve 16-20 kıdeme sahip olan öğretmenlerden oluşmaktadır. Görev yaptıkları kuruma çok bağlı olan, 1-5, 6-10, 21 ve üzeri kıdeme sahip olan öğretmenlerin tatmin boyutuna ilişkin \%81.03'ü olumlu tutuma; \% 16.38'i orta düzeyde tutuma; \%2.6's1 olumsuz tutuma sahiptirler. Görev yaptıkları kuruma çok bağlı olan, 11-15 ve 16-20 kıdeme sahip olan öğretmenlerin 
tatmin boyutuna ilişkin \%58.24'ü olumlu tutuma; \% 38.46's1 orta düzeyde tutuma; \%3.3'ü olumsuz tutuma sahiptirler.

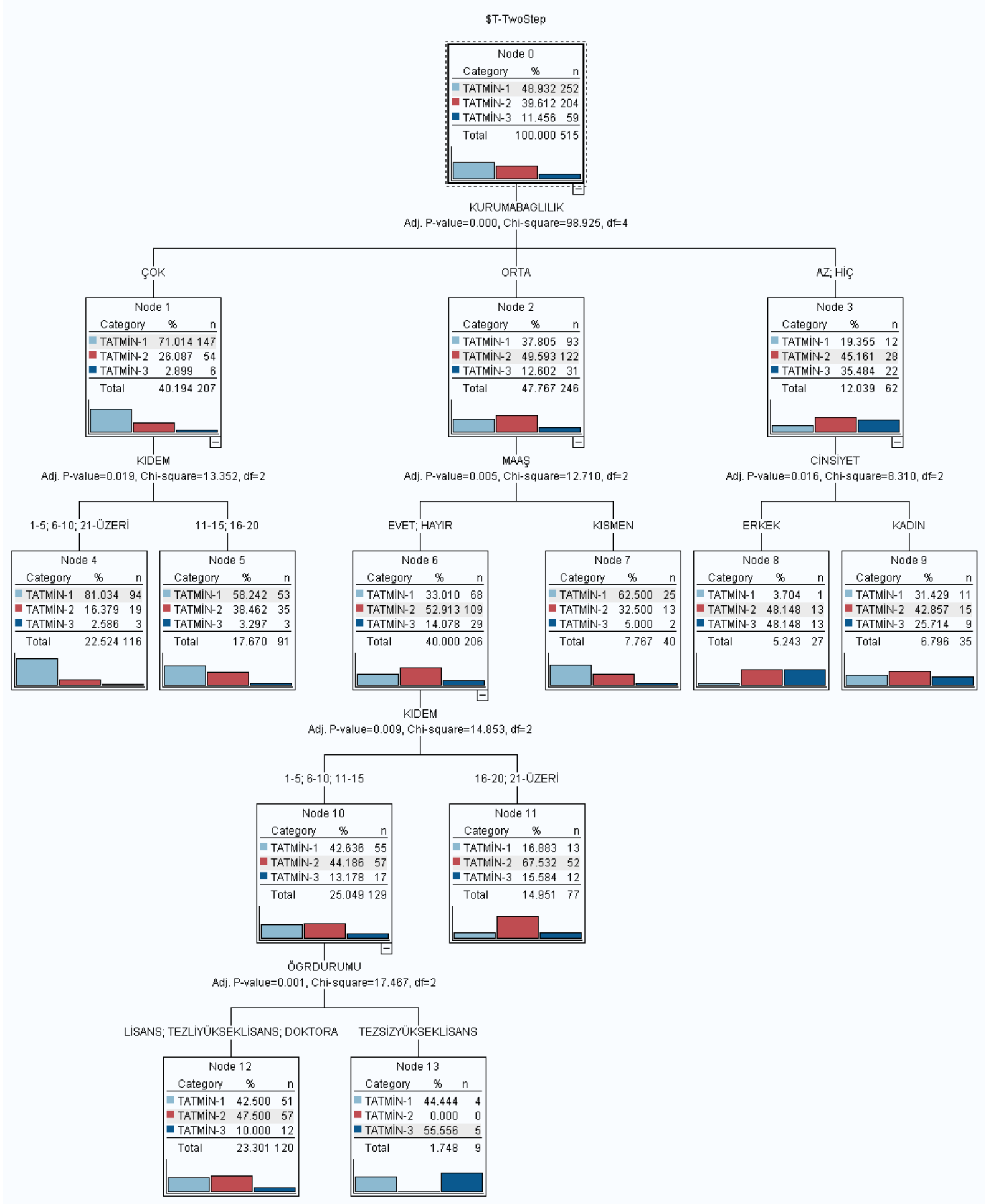

Şekil 2. "Tatmin" boyutuna ilişkin CHAID analizi sonuçları 
Görev yaptıkları kuruma orta düzeyde bağlı olan öğretmenlerin oluşturduğu kümeyi en iyi açıklayan değişken, "maaşı yeterli bulup bulmama durumu" dur $\left(\chi^{2}=\right.$ 12.710; $p=0.005)$. Bu değişken bağımlı değişkeni iki gruba ayırmış olup, gruplar arasında anlamlı farklılıklar elde edilmiştir. Görev yaptıkları kuruma orta düzeyde bağlı olan öğretmenlerin \%83.74'ü aldıkları maaşı yeterli ya da yetersiz bulmakta; \%16.26'sı ise kısmen yeterli bulmaktadır. Görev yaptıkları kuruma orta düzeyde bağlı olan, aldıkları maaşı yeterli ya da yetersiz bulan öğretmenlerin tatmin boyutuna ilişkin \%52.91'i orta düzeyde tutuma; \% 33.01'i olumlu tutuma; \%14.08'i olumsuz tutuma sahiptirler. Görev yaptıkları kuruma orta düzeyde bağlı olan, aldıkları maaşı kısmen yeterli bulan öğretmenlerin tatmin boyutuna ilişkin \%62.50'si olumlu tutuma; \% 32.50'si orta düzeyde tutuma; \%5.00'i olumlu tutuma sahiptirler.

Görev yaptıkları kuruma az bağlı olan ya da hiç bağlı olmayan öğretmenlerin oluşturduğu kümeyi en iyi açılayan değişken "cinsiyet"tir $\left(\chi^{2}=8.310 ; p=0.016\right)$. Görev yaptıkları kuruma az bağlı olan ya da hiç bağlı olmayan öğretmenlerin \%56.45’i kadın öğretmenlerden oluşurken; \%43.55'i erkek öğretmenlerden oluşmaktadır. Görev yaptıkları kuruma az bağlı olan ya da hiç bağlı olmayan erkek öğretmenlerin \%48.15'i tatmin boyutuna ilişkin orta düzey ve olumsuz tutuma; \% 3.70'i olumlu tutuma sahiptirler. Görev yaptıkları kuruma az bağlı olan ya da hiç bağlı olmayan kadın öğretmenlerin \%42.86'sı tatmin boyutuna ilişkin orta düzeyde tutuma; \%31.43'ü olumlu tutuma; \%25.71'i olumsuz tutuma sahiptirler.

Görev yaptıkları kuruma orta düzeyde bağlı olan, aldıkları maaşı yeterli ya da yetersiz bulan öğretmenlerin oluşturduğu kümeyi en iyi açıklayan değişken ise "kıdem" dir $\left(\chi^{2}=14.853 ; p=0.009\right)$. Bu değişken bağımlı değişkeni iki gruba ayırmış olup gruplar arasında anlamlı farklılıklar elde edilmiştir. Görev yaptıkları kuruma orta düzeyde bağlı olan, aldıkları maaşı yeterli ya da yetersiz bulan öğretmenlerin \%62.62'si 1-5, 6-10 ve 11-15 k1deme sahip olan öğretmenlerden; \%37.38'i 16-20; 21 ve üzeri kıdeme sahip olan öğretmenlerden oluşmaktadır. Görev yaptıkları kuruma orta düzeyde bağlı olan, aldıkları maaşı yeterli ya da yetersiz bulan, 1-5, 6-10 ve 11-15 kıdeme sahip olan öğretmenlerin \%44.19'u tatmin boyutuna ilişkin orta düzeyde tutuma; \% 42.64'ü olumlu tutuma ve \%13.18'i olumsuz tutuma sahiptirler. Görev yaptıkları kuruma orta düzeyde bağlı olan, aldıkları maaşı yeterli ya da yetersiz bulan, 16-20; 21 ve üzeri kıdeme sahip olan öğretmenlerin \%67.53'ü tatmin boyutuna ilişkin orta düzey tutuma; \%16.88'i olumlu tutuma ve \%15.58'i olumsuz tutuma sahiptirler.

Görev yaptıkları kuruma orta düzeyde bağlı olan, aldıkları maaşı yeterli ya da yetersiz bulan, 1-5, 6-10 ve 11-15 kıdeme sahip olan öğretmenlerin oluşturduğu kümeyi en iyi açıklayan değişken ise "öğrenim durumu" dur $\left(\chi^{2}=17.467 ; p=0.001\right)$. $\mathrm{Bu}$ değişken bağımlı değişkeni iki gruba ayırmış olup, gruplar arasında anlamlı farklılıklar elde edilmiştir. Görev yaptıkları kuruma orta düzeyde bağlı olan, aldıkları maaşı yeterli ya da yetersiz bulan, 1-5, 6-10 ve 11-15 kıdeme sahip olan öğretmenlerin \%93.02' si lisans, tezli yüksek lisans ve doktora mezunu öğretmenlerden; \%6.98'i tezsiz yüksek lisans mezunu öğretmenlerden oluşmaktadır. Görev yaptıkları kuruma orta düzeyde bağlı olan, aldıkları maaşı yeterli ya da yetersiz bulan, 1-5, 6-10 ve 11-15 kıdeme sahip olan, lisans, tezli yüksek lisans ve doktora mezunu öğretmenlerin $\% 47.50$ 'si tatmin boyutuna ilişkin orta düzeyde tutuma; \% 42.50'si olumlu tutuma ve $\%$ 10.00'1 olumsuz tutuma sahiptirler. Görev yaptıkları kuruma orta düzeyde bağl1 olan, aldıkları maaşı yeterli ya da yetersiz bulan, 1-5, 6-10 ve 11-15 kıdeme sahip olan, 
tezsiz yüksek lisans mezunu öğretmenlerin \%55.56'sı tatmin boyutuna ilişkin olumsuz tutuma; \% 44.44'ü olumlu tutuma sahiptirler.

Öğretmenlik mesleğine yönelik tutum ölçeğinin “değer" alt boyutuna ilişkin toplam puana ait İki Aşamalı Kümeleme Analizi sonuçları Tablo 4'te verilmiştir.

Tablo 4.

"Değer" boyutuna ilişkin toplam puana ait İki Aşamalı Kümeleme Analizi sonuçları

\begin{tabular}{lcccc}
\hline Kümeleme & $\mathrm{N}$ & $\overline{\mathrm{X}}$ & $\mathrm{SS}$ & $\%$ \\
\hline 1.Küme (Olumlu)-Değer 1 & 280 & 38.97 & 1.13 & 54.37 \\
2.Küme (Eşik/Orta düzey)-Değer 2 & 177 & 33.83 & 1.83 & 34.37 \\
3.Küme (Olumsuz)-Değer 3 & 58 & 24.71 & 3.62 & 11.26 \\
\hline
\end{tabular}

Tablo 4'e göre, birinci kümede (olumlu) 280 (\%54.37) öğretmen yer almakta ve toplam puan ortalamaları 38,97 \pm 1.13 değerinde; ikinci kümede (eşik/orta düzey) 177 (\%34.37) öğretmen yer almakta ve toplam puan ortalamaları 33,83 \pm 1.83 değerinde ve üçüncü kümede (olumsuz) ise 58 (\%11.26) öğretmen yer almakta ve toplam puan ortalamaları 24,71 \pm 3.62 değerindedir. İkinci küme eşik değer olarak ele alınmış olup, toplam puanı eşik değerin üstünde olan öğretmenlerin "değer" boyutuna ilişkin olumlu tutuma, eşik değerin altında puan alan öğretmenlerin ise olumsuz tutuma sahip oldukları söylenebilir.

Öğretmenlik mesleğine yönelik tutum ölçeğinin "değer" alt boyutuna ilişkin CHAID analizi ile elde edilen karar ağacı, Şekil 3 'te gösterilmiştir.

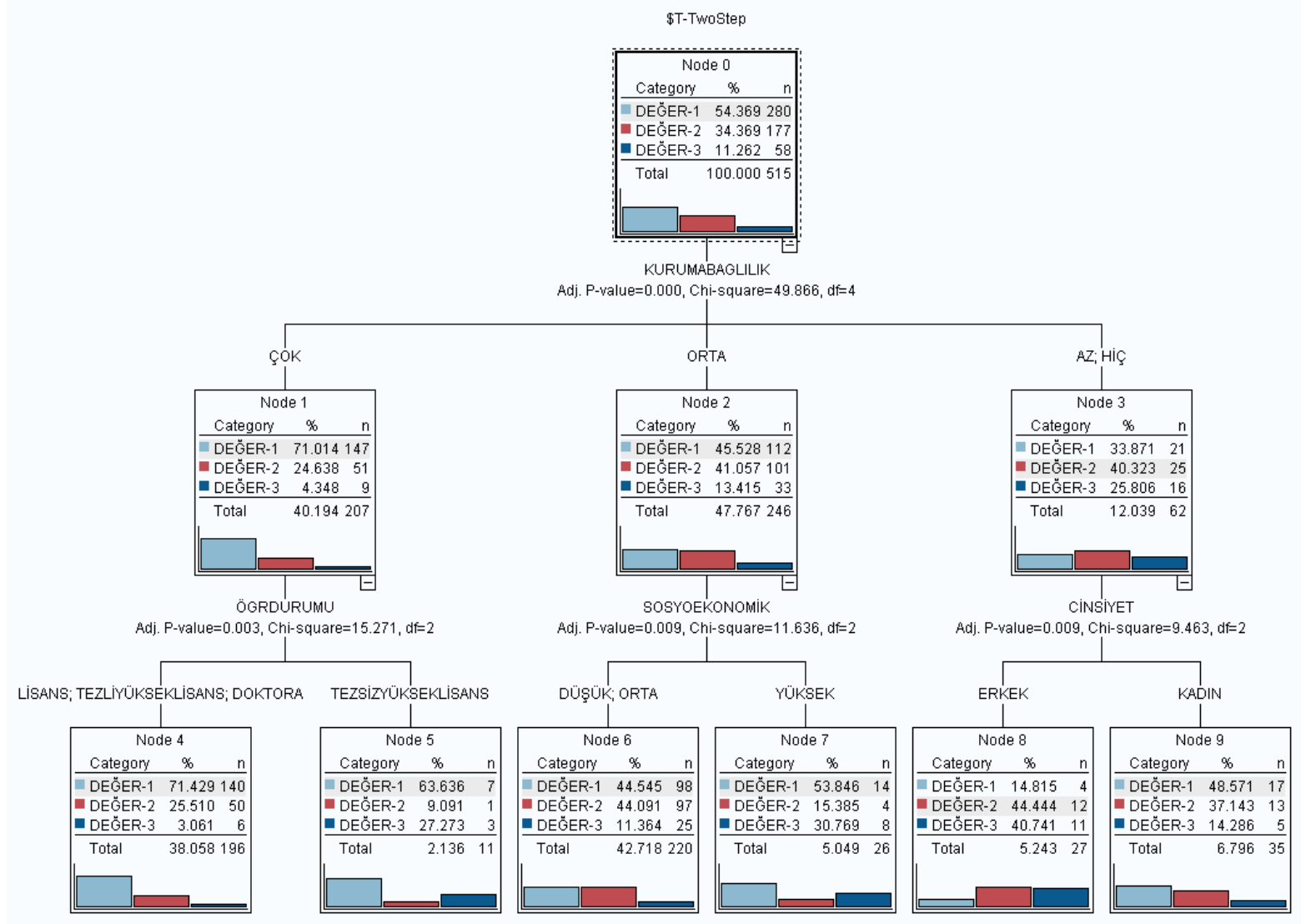

Şekil 3. "Değer" boyutuna ilişkin CHAID analizi sonuçları 
Şekil 3 incelendiğinde, CHAID analizi sonucuna göre "değer" boyutunu açıklayan 9 düğüm bulunmuştur. "Değer" boyutunu en iyi açıklayan değişken öğretmenlerin "çalışılan kuruma hissedilen bağlılık düzeyi" dır $\left(\chi^{2}=49.866 ; p=0.000\right)$. $\mathrm{Bu}$ değişken bağımlı değişkeni üç gruba bölmüş olup, gruplar arasında anlamlı farklılıklar elde edilmiştir. Öğretmenlerin \%47.77'si görev yaptıkları kuruma orta düzeyde bağlı olan öğretmenlerden, \%40.19'u görev yaptıkları kuruma çok bağlı olan öğretmenlerden, \%12.04' ü az bağlı olan ya da hiç bağlı olmayan öğretmenlerden oluşmaktadır. Görev yaptıkları kuruma çok bağlı olan öğretmenlerin \%71.01'i değer boyutuna ilişkin olumlu tutuma; \%24.64'ü orta düzeyde tutuma; \%4.35'i olumsuz tutuma sahiptirler. Görev yaptıkları kuruma orta düzeyde bağlı olan öğretmenlerin değer boyutuna ilişkin \%45.53'ü olumlu tutuma; \%41.06's1 orta düzeyde tutuma; \%13.42' si olumsuz tutuma sahiptirler. Görev yaptıkları kuruma az bağlı olan ya da hiç bağlı olmayan öğretmenlerin \%40.32'si değer boyutuna ilişkin orta düzeyde tutuma; \%33.87'si olumlu tutuma; \% 25.81'i olumsuz tutuma sahiptirler.

Görev yaptıkları kuruma çok bağlı olan öğretmenlerin oluşturduğu kümeyi en iyi açıklayan değişken, "öğrenim durumu” dur $\left(\chi^{2}=15.271 ; p=0.003\right)$. Bu değişken bağımlı değişkeni iki gruba ayırmış olup, gruplar arasında anlamlı farklılıklar elde edilmiştir. Görev yaptıkları kuruma çok bağlı olan öğretmenlerin \%94.69’u lisans, tezli yüksek lisans ve doktora mezunu öğretmenlerden; \%5.31'i ise tezsiz yüksek lisans mezunu öğretmenlerden oluşmaktadır. Görev yaptıkları kuruma çok bağlı olan, lisans, tezli yüksek lisans ve doktora mezunu öğretmenlerin değer boyutuna ilişkin \%71.43'ü olumlu tutuma; \% 25.51'i orta düzey tutuma; \%3.06's1 olumsuz tutuma sahiptirler. Görev yaptıkları kuruma çok bağlı olan, tezsiz yüksek lisans mezunu öğretmenlerin değer boyutuna ilişkin \%63.64'ü olumlu tutuma; \% 27.27'si olumsuz tutuma; \%9.09'u orta düzey tutuma sahiptirler.

Görev yaptıkları kuruma orta düzeyde bağlı olan öğretmenlerin oluşturduğu kümeyi en iyi açıklayan değişken, “okullarının sahip olduğu sosyoekonomik düzey" dir $\left(\chi^{2}=11.636 ; p=0.009\right)$. Bu değişken bağımlı değişkeni iki gruba ayırmış olup, gruplar arasında anlamlı farklılıklar elde edilmiştir. Görev yaptıkları kuruma orta düzeyde bağlı olan öğretmenlerin \%89.43'üne göre sosyoekonomik düzeyi düşük ve orta düzey olan okullarda; \%10.57'sine göre sosyoekonomik düzeyi yüksek olan okullarda görev yapmaktadırlar. Görev yaptıkları kuruma orta düzeyde bağlı olan, sosyoekonomik açıdan düşük ve orta düzey okullarda görev yaptıklarını belirten öğretmenlerin değer boyutuna ilişkin \%44.55'i olumlu tutuma; \% 44.09'u orta düzey tutuma; \%11.36'sı olumsuz tutuma sahiptirler. Görev yaptıkları kuruma orta düzeyde bağlı olan, sosyoekonomik açıdan yüksek düzey okullarda görev yaptıklarını belirten öğretmenlerin değer boyutuna ilişkin \%53.85'i olumlu tutuma; \% 30.77'si olumsuz tutuma; \%15.39'u orta düzey tutuma sahiptirler.

Görev yaptıkları kuruma az bağlı olan ya da hiç bağlı olmayan öğretmenlerin oluşturduğu kümeyi en iyi açıklayan değişken "cinsiyet"tir $\left(\chi^{2}=9.463 ; p=0.009\right)$. Bu değişken bağımlı değişkeni iki gruba ayırmış ve bu gruplar arasında anlamlı farklılıklar elde edilmiştir. Görev yaptıkları kuruma az bağlı olan ya da hiç bağlı olmayan öğretmenlerin, \%43.55'i erkek öğretmenlerden oluşurken; \%56.45'i kadın öğretmenlerden oluşmaktadır. Görev yaptıkları kuruma az bağlı olan ya da hiç bağlı olmayan erkek öğretmenlerin \%44.44'ü değer boyutuna ilişkin orta düzey tutuma; \% 40.74'ü olumsuz tutuma; \%14.82'si olumlu tutuma sahiptirler. Görev yaptıklar1 
kuruma az bağlı olan ya da hiç bağlı olmayan, kadın öğretmenlerin \%48.57'si değer boyutuna ilişkin olumlu tutuma; \% 37.14'ü orta düzeyde tutuma; \%14.29'u olumsuz tutuma sahiptirler.

\section{Tartışma, Sonuç ve Öneriler}

Öğretmenlerin mesleki gelişimi için sahip oldukları tutumlar çok önemlidir. Bir öğretmenin öğretmen olarak görevini nasıl yerine getireceği, büyük ölçüde mesleğine karşı tutumlarına, değerlerine ve inançlarına bağlıdır. Bununla birlikte bir öğretmenin tutumu öğrencilerinin davranışlarını da etkilemektedir (Kumar, 2016). Dolayısıyla etkili ve verimli öğrenme, ancak olumlu tutuma sahip öğretmenler tarafından sağlanabilir. (Pancholi ve Bharwad, 2015). Öğretmenlerin mesleki tutumlarına etki eden değişkenlerin incelendiği bu araştırmada öğretmenlik mesleğine yönelik tutum ölçeğinin alt boyutları olan sevgi, tatmin ve değer boyutları üzerinde öğretmenlerin çoğunluğu olumlu tutuma sahiptirler. Buna göre, öğretmenlerin çoğunun; mesleklerini sevdikleri, mesleki tatminlerinin yüksek olduğu ve mesleklerine değer verdikleri söylenebilir. Benzer şekilde yapılan araştırmalarda da (Doğan, 2013; Güloğlu Demir, 2016; Piji Küçük, 2012; Polat, Arslan ve Satıc1, 2016) öğretmenlerin mesleklerine yönelik olumlu tutumlara sahip olduğu ortaya çıkmıştır. Mesleklerine yönelik olumlu tutumlara sahip olan öğretmenlerin motivasyonları üst düzeyde olur, mesleklerini etkili ve verimli bir şekilde icra edebilmeleri için görevlerini, sorumluluklarını ve rollerini daha iyi bir şekilde sahiplenirler, öğrenme ve öğretmeyi kolaylaştırarak başarıyı artırırlar. Karataş ve Güleş'e (2010) göre öğretmenlerin mesleki tatminlerinin yüksek olması onların motivasyon ve verimliliğini arttırarak mesleklerinde başarılı olmaları için önemli bir unsur iken mesleki tatminsizlikleri ise bireyde birtakım psikolojik sorunlar oluşturarak, çalıştıkları kuruma yabancılaşma ve verimliliğin azalmasıyla başarısızlık ile sonuçlanabilir. Dolayısıyla öğrenme-öğretme sürecinin başrolünde olan öğretmenlik mesleğinin gerekliliklerini yerine getirmede, öğretmenlerin mesleklerini sevmesi, mesleklerine değer vermesi ve mesleki tatminlerinin yüksek olması istenilen ve son derece önemli olan bir durumdur.

Sevgi, tatmin ve değer alt boyutları üzerinde etki düzeyi en yüksek olan bağımsız değişken, "çalışılan kuruma hissedilen bağlılık düzeyi"dir. Kurumsal bağlılık, çalışanların kurumda kalma ya da ayrılma eğiliminin en önemli belirleyicilerinden birisidir (Duygulu ve Abaan, 2007). Başka bir ifadeyle kurumsal bağlılık, örgüte karşı takınılan bir tutum veya yöneliştir (Sheldon, 1971; Akt: Gül, 2002). Tutumlar, bireylerin bir nesneye, kişiye veya bir gruba, kuruma veya olaylara olumlu veya olumsuz yanıt verme eğilimini ifade eder (Elina, 2016). Başka bir ifadeyle, bir şey hakkında belirli bir duygu, bir durum hakkında bilgi ve deneyim ve beklentiye dayalı bir duygudur (Zarzolawmi, 2019). Tutumlar, duyuşsal özellikler bağlamında ele alınan özelliklerden biridir (Oral, 2004). Kurumsal bağl1lıklarda da duygusal faktörler çok etkilidir (Kılıç, 2008). Kurumsal bağlılık faktörleri, çalışanların tutum ve davranışları üzerinde doğrudan etkilidir (Gül, 2002). Kurumsal bağlılık çalışanın örgütle ilgili tutumlarına önem verdiği için (Bilgiç, 2017) araştırmada, etki düzeyi en yüksek olan bağımsız değişkenin "çalışılan kuruma hissedilen bağlılık düzeyi” olması beklenen bir durumdur. Tadesse (2019) kurumsal bağlılığın rol stresi, motivasyon, iş güvensizliği, iş performansı, istihdam edilebilirlik ve liderlik gibi bazı faktörlerle bağlantılı olduğunu ifade etmiştir. Bilgiç (2017) de iş tatmini ile örgütsel bağlılı̆̆ 
birlikte değerlendirdiğinde kaçınılmaz olarak birbirleri ile ilişkili olduğunu belirtmiştir. Nagar'a (2012) göre daha fazla iş tatmini, örgütsel bağlılığın artmasına önemli ölçüde katkıda bulunmaktadır. Bu araştırmada öğretmenlerin büyük bir kısmı çalıştıkları kuruma çok ve orta düzeyde bağlı olan öğretmenlerden oluşmaktadır. Benzer şekilde Karakaya ve Karademir (2013) öğretmenlerin; çalıştıkları kurumlarına karşı örgütsel bağlılıklarının olumlu bir seviyede olduğunu, mesleklerine ve çalıştıkları kuruma karşı bağlılık ifade ettiklerini tespit etmişlerdir. Chan, Lau, Lim ve Hogan'a (2008) göre, öğretmenlerin örgütsel bağlılı̆̆ının olumlu sonuçları arasında daha yüksek iş tatmini, daha düşük işten ayrılma oranı, en aza indirilmiş devamsızlık, iyileştirilmiş örgütsel vatandaşlık davranışı ve artan öğrenci başarısı bulunmaktadır. Ayrıca, yüksek örgütsel bağlılığa sahip öğretmenlerin performansları olumlu etkilenmekte, hizmet kaliteleri yükselmekte ve olumsuz davranışları azalmaktadır. Dolayısıyla, çalışanların kurumsal bağlılıkları gerçek başarıyı elde edebilmede son derece önemlidir (Karataş ve Güleş, 2010). O halde öğretmenlerin çalıştıkları kuruma karşı örgütsel bağlılıklarının olumlu düzeyde olması istenilen bir durumdur. Sevgi, tatmin ve değer alt boyutlarında çalıştıkları kuruma yüksek düzeyde bağlı olan öğretmenler düşük düzeyde bağlı olan öğretmenlere göre anlamlı bir şekilde daha olumlu tutuma sahiptirler. Buna göre çalıştıkları kuruma yüksek düzeyde bağlı olan öğretmenlerin düşük düzeyde bağlı olan öğretmenlere göre mesleklerini daha fazla sevdikleri, mesleki tatminlerinin daha yüksek olduğu ve mesleklerine daha çok değer verdikleri söylenebilir. Benzer şekilde Karataş ve Güleş'in (2010) yaptıkları araştırma sonucunda; öğretmenlerin mesleki tatminleri ile kurumsal bağlılıkları arasında pozitif, yüksek düzeyde bir ilişki olduğu tespit edilmiştir. Dolayısıyla kişinin kurumuna karşı hissettiği bağlılık düzeyinin yüksek olması, genel olarak mesleğine karşı olumlu duygular içinde olduğunun bir göstergesi olduğu söylenebilir.

Sevgi, tatmin ve değer alt boyutlarında görev yaptıkları kuruma az bağlı olan ya da hiç bağlı olmayan öğretmenlerin oluşturduğu kümeyi en iyi açıklayan değişken "cinsiyet"tir. Genel olarak görev yaptıkları kuruma az bağlı olan ya da hiç bağlı olmayan kadın öğretmenler, erkek öğretmenlere göre anlamlı bir şekilde daha olumlu tutuma sahiptirler. Buna göre kadın öğretmenlerin erkek öğretmenlere kıyasla mesleklerini daha çok sevdikleri, mesleki tatminlerinin daha yüksek olduğu ve mesleklerine daha fazla değer verdikleri söylenebilir. Piji Küçük (2012) ve Güloğlu Demir (2016) tarafından yapılan bir araştırmada; kadın öğretmenlerin mesleklerine yönelik tutumlarının daha olumlu olmasına rağmen puanlar arasındaki farkın istatistiki açıdan anlamlı olmadığı ortaya çıkmıştır. Bhargava ve Pathy (2014) bazı araştırmalarda, kadın öğretmenlerin erkek öğretmenlere göre daha yüksek bir tutuma sahip olduklarını ve olumlu tutuma sahip öğretmenlerin öğrencilerini teşvik etme eğiliminde olduklarını belirtmişlerdir. Strong (1943), kültürlerin bazı meslekleri öncelikle kadınlara bazılarını ise erkeklere özgü saydığını belirtmektedir (Baykara Pehlivan, 2008). Bizim toplumumuzda öğretmenlik mesleği genellikle kadınlarla özdeşleştirilmektedir. Yaman, Yaman ve Eskicumalı (2001) tarafından yapılan araştırmada da; katılımcıların \%70 gibi büyük çoğunluğu öğretmenlik mesleğini bayan mesleği olarak görmektedir. Bu şekildeki bir algının, bayan öğretmenlerin meslekleri daha çok sahiplenmelerine neden olup öğretmenlik mesleğine karş1 tutumlarını olumlu yönde etkileyebileceği düşünülebilir. Korkmaz ve Sadık (2011) tarafından yapılmış olan bir araştırmada ise erkek öğretmenlerin mesleklerine yönelik 
tutumlarının daha olumlu olmalarına rağmen, bu farkın sonucu anlamlı ölçüde etkilemediği tespit edilmiştir.

Sevgi boyutu üzerinde, çalıştıkları kuruma orta düzeyde bağlı olan öğretmenlerin oluşturduğu kümeyi en iyi açıklayan değişken "maaşı yeterli bulup bulmama durumu"dur. Görev yaptıkları kuruma orta düzeyde bağlı olan öğretmenlerin büyük bir kısmı aldıkları maaşı yeterli bulmamaktadır. Genel olarak çalıştıkları kuruma orta düzeyde bağlı olan öğretmenlerden maaşı yeterli bulanlar bulmayanlara göre sevgi boyutuna ilişkin anlamlı bir şekilde daha olumlu tutuma sahiptirler. Başka bir ifadeyle çalıştıkları kuruma orta düzeyde bağlı olan öğretmenlerden maaşı yeterli bulanların bulmayanlara göre mesleklerini daha çok sevdikleri söylenebilir. Gürsoy (2009) ve Bilgin'in (1996) yaptıkları araştırmalarda öğretmenlerin mesleki tutumlarının aldıkları maaştan kısmen etkilendikleri tespit edilmiştir. Karataş ve Güleş (2010)'e göre öğretmenlerin mesleki tatminlerini en olumsuz yönde etkileyen unsur maaştır. Özyürek ve Erbay (2015)'e göre ise gelir düzeyi, insanların yaşamını ve mutluluğunu önemli düzeyde etkileyebilmekte; maaşın yetersiz oluşunun, bireylerin yaşamlarını olumsuz yönde etkileyerek mesleklerine karşı olumsuz tutumlar sergilemelerine neden olabilmektedir. Çünkü bir mesleğe olan ilgiyi, toplumun bakış açısını o meslekten elde edinilen ekonomik kazanç belirlemektedir.

Değer alt boyutu üzerinde çalıştıkları kuruma orta düzeyde bağlı olan öğretmenlerin oluşturduğu kümeyi en iyi açıklayan değişken “okullarının sahip olduğu sosyoekonomik düzey" dir. Görev yaptıkları kuruma orta düzeyde bağlı olan öğretmenlerin büyük kısmı sosyoekonomik düzeyi orta ve düşük düzey okullarda görev yaptıklarını belirtirken, çok az kısmı sosyoekonomik düzeyi yüksek olan okullarda çalıştıklarını ifade etmektedirler. Görev yaptıkları kuruma orta düzeyde bağlı olan, sosyoekonomik açıdan yüksek düzey okullarda görev yaptıklarını belirten öğretmenlerin düşük ve orta düzey okullarda görev yaptıklarını belirten öğretmenlere göre anlamlı bir şekilde daha olumlu tutuma sahiptirler. Başka bir ifadeyle görev yaptıkları kuruma orta düzeyde bağlı olan, sosyoekonomik açıdan yüksek düzey okullarda görev yaptıklarını belirten öğretmenlerin mesleklerine daha çok değer verdikleri söylenebilir.

Tatmin alt boyutu üzerinde çalıştıkları kuruma çok bağlı olan öğretmenlerin oluşturduğu kümeyi, en iyi açıklayan değişken "kıdem" dir. Görev yaptıkları kuruma çok bağlı olan, 1-5, 6-10, 21 ve üzeri kıdeme sahip olan öğretmenlerin tatmin boyutuna ilişkin 11-15 ve 16-20 kıdeme sahip olanlara göre anlamlı bir şekilde daha olumlu tutuma sahiptirler. Buna göre görev yaptıkları kuruma çok bağlı olan, 1-5, 6-10, 21 ve üzeri kıdeme sahip olan öğretmenlerin mesleki tatminlerinin daha yüksek olduğu söylenebilir. Piji Küçük (2012) tarafından yapılan bir araştırmada öğretmenlerin mesleklerine yönelik tutumlarının kıdemlerine göre anlamlı bir fark yaratmadığı ortaya çıkmıştır.

Değer alt boyutu üzerinde çalıştıkları kuruma çok bağlı olan öğretmenlerin oluşturduğu kümeyi en iyi açılayan değişken "öğrenim durumu"dur. Çalıştıkları kuruma çok bağlı olan lisans, tezli yüksek lisans, doktora mezunu öğretmenler tezsiz yüksek lisans mezunu öğretmenlere göre değer boyutuna ilişkin anlamlı bir şekilde daha olumlu tutuma sahiptirler. Bu bulgu çalıştıkları kuruma çok bağlı olan lisans, tezli yüksek lisans, doktora mezunu öğretmenlerin tezsiz yüksek lisans mezunu 
öğretmenlere göre mesleklerine daha fazla değer verdikleri anlamına gelmektedir. Ortaöğretim alan öğretmenliği için getirilen tezsiz yüksek lisans programı ile eğitim fakültesi dışındaki öğrencilere öğretmen olma hakkı verilmekteydi (Özoğlu, 2010). YÖK, 2009 ve 2010 yıllarında tezsiz yüksek lisans programlarını yeniden düzenlemiştir (Aynal Kilimci, 2011). YÖK 21 Ocak 2010 tarihli duyurusuyla eğitim fakültesi dışındaki öğrencilerin öğretmen olmak için mezuniyetten sonra aldıkları tezsiz yüksek lisans eğitimine yerine pedagojik formasyon sertifika eğitimine dönüştürülmesine karar verilmiştir. Dolayısıyla eğitim fakültesi dışındaki öğrenciler mezuniyetten sonra aldıkları tezsiz yüksek lisans yeni haliyle pedagojik formasyon eğitimi ile öğretmen olmaya hak kazanmaktadırlar (Azar, 2011). Turhan Türkkan, Yeşilpınar Uyar ve Yolcu (2017), konu ile ilgili yapılan çalışmalardan yaptığı çıkarım sonucunda pedagojik formasyon eğitimi almakta olan öğrencilerin, bu eğitimi öğretmen olabilmek için bir mecburiyet olarak nitelendirdiklerini, programı gereksiz ve yetersiz gördüklerini, uygulamada ortaya çıkan sıkıntılardan, sorunlardan dolayı olumsuz düşüncelere sahip olduklarını ifade etmişlerdir. Bu gibi olumsuz düşüncelerin, tezsiz yüksek lisans mezunu öğretmenlerin mesleğe yönelik tutumlarını olumsuz etkilediği söylenebilir. Güloğlu Demir (2016) eğitim fakültesi dişı bir kurumdan mezun olan öğretmenlerin, öğretmenlik mesleğine yönelik tutumlarının daha az olduğunu tespit etmiştir. Buna rağmen Polat (2013) ve Bağçeci, Yıldırım, Kara ve Keskinpalta (2015) tarafından yapılan araştırmalarda pedagojik formasyon eğitimi alan öğrencilerin eğitim fakültelerinden mezun olanlara göre öğretmenlik mesleğine ilişkin tutumlarının daha olumlu olmaları dikkat çekmektedir.

Araştırmada ortaya çıkan önemli bir sonuç, öğretmenlerin görev yaptıkları kuruma karşı bağlılıklarının mesleki tutumlarını etkilediği şeklindedir. Öğretmenlerin kuruma karşı bağlılıklarını arttırmak için özellikle yöneticilere görev düşmektedir. Bu hususta, okul yöneticisi-öğretmen ilişkisini olumlu yönde arttıracak kültürel ve sportif etkinlikler düzenlenebilir ve bu etkinliklere katılım teşvik edilebilir. Öğretmenlerin, okul ile alınacak kararlarda aktif katılımlarını sağlamak amacıyla görüşlerine yer verilebilir. Yöneticilerin öğretmenler üzerinde baskı kurmamaları ve gereksiz gözetimden kaçınmaları sağlanabilir. Öğretmenlerin ihtiyaçlarını karşılayacak işlevsel bir çalışma ortamı oluşturulabilir. Bununla birlikte araştırmanın bir başka önemli sonucu, öğretmenlerin mesleki tutumlarının aldıkları maaştan etkilendiği şeklindedir. Bu durumda öğretmenlerin tatmin olacakları, hayat standartlarını yükseltecek bir gelir düzeyine ulaşması sağlanabilir.

$\mathrm{Bu}$ araştırmada karar ağacı modellerinden biri olan CHAID analizi tercih edilmiştir. Bu analiz, regresyon problemlerinde kullanılabileceği gibi karar ağaçlarının oluşturulmasında da etkilidir (Pehlivan, 2006). Diğer karar ağacı modellerine göre kategorik ve sürekli değişkenler üzerinde çalışabilmesi, ağaçta her düğümü ikiden fazla alt gruba ayırabilmesi gibi avantajlarından dolayı günümüzde en yaygın kullanılan karar ağacı modelidir (Ekici, 2012). CHAID analizi regresyon analizine göre de daha detaylı ve anlaşılır sonuç vermesi, bağımsız değişkenler arasındaki ortak etkiyi açıklaması ve bağımlı değişken ile bağımsız değişkenler arasında detaylı bilgiler sağlaması açısından sınıflandırma çalışmalarında daha fazla tercih edilebilir (Şata, 2015). Ancak, bu yöntem sürekli verileri doğrudan işleyemediği için analiz öncesinde verilerin kategorik değişkenlere dönüştürülmesi gerekmektedir. Öte yandan, bu analiz her ağaç seviyesinde çok küçük olabilecek birkaç gruba bölündüğü için 
örneklem sayısının fazla olmasını gerekmektedir (Milanović ve Stamenković, 2016). Bu nedenle, eğitim bilimleri alanında yapılan başka araştırmalarda farklı karar ağacı modelleri kullanılarak sınıflandırma performansları karşılaştırılabilir.

$\mathrm{Bu}$ araştırma Diyarbakır ilinde görev yapan 515 öğretmenden elde edilen verilerle sınırlıdır. Farklı illerde daha büyük örneklemlerle benzer araştırmalar yapılabilir. Bu araştırma öğretmenlerin mesleklerine yönelik tutumlarına etki eden değişkenleri belirlemeye yönelik nicel bir araştırmadır. Öğretmenlerin mesleklerine yönelik tutumlarını ele alan nitel veya karma araştırmalar yapılabilir.

\section{Kaynakça}

Aggarwal, J. C. (2010). Teacher and education in a developing society. Noida, India: Vikas Publishing House Private Limited. https:/ / doi.org/10.1177/0022487109354521

Akgün, F., ve Özgür, H. (2014). Bilişim teknolojileri öğretmen adaylarının öğretmenlik mesleğine ilişkin tutumları ile mesleki kaygılarının incelenmesi. Ë̆itimde Kuram ve Uygulama, 10(5), 1206-1223.

Alkhateeb, H. M. (2013). Attitudes towards teaching profession of education students in Qatar. Comprehensive Psychology, 2(9), 1-5. https://doi.org/10.2466/01.03.IT.2.9

Althuwaynee, O. F., Pradhan, B., and Ahmad, N. (2014). Landslide susceptibility mapping using decision-tree based $\mathrm{CHi}$-squared automatic interaction detection (CHAID) and logistic regression (LR) integration. In IOP Conference Series: Earth and Environmental Science, IOP Publishing. https:/ / doi.org/10.1088/1755-1315/20/1/012032

Al-Zaidiyeen, N. J., Lai Mei, L., and Fook, F. S. (2010). Teachers attitude and levels of technology use in classroom. The case of Jordan schools. International Education Studies, 3(2), 211-218. https:/ / doi.org/10.5539/ies.v3n2p211

Amalita, N., Kurniawati, Y., and Fitria, D. (2019). Characteristics of bidikmisi's scholarship awardee in FMIPA UNP using chi-squared automatic interaction detection. In Journal of Physics: Conference Series, IOP Publishing. https:/ / doi.org/10.1088/1742-6596/1317/1/012012

Atasoy, R., ve Güçlü, N. (2020). PIAAC 2015 sonuçlarına göre Türkiye'deki yetişkinlerin sözel okuryazarlık becerilerinin değerlendirilmesi. Hacettepe Üniversitesi Ĕ̆itim Fakültesi Dergisi, 35(4), 915-935. https:/ / doi.org/10.16986/HUJE.2019053682

Atieh, M. A., Pang, J. K., Lian, K., Wong, S., Tawse-Smith, A., Ma, S., and Duncan, W. J. (2019). Predicting peri-implant disease: Chi-square automatic interaction detection (CHAID) decision tree analysis of risk indicators. Journal of periodontology, 90 (8), 834-846.

Aynal Kilimci, S. (2011). Türkiye'de öğretmen olmak. S. Aynal Kilimci (Ed.). Türkiye'de öğretmen yetiştirme içinde (s. 117-133). Ankara: Pegem Akademi Yayincilik.

Azar, A. (2011). Türkiye' deki öğretmen eğitimi üzerine bir söylem: Nitelik mi, nicelik mi? Yükseköğretim ve Bilim Dergisi, 1(1), 36-38.

Bağçeci, B., Yıldırım, İ., Kara, K., ve Keskinpalta, D. (2015). Pedagojik formasyon ve eğitim fakültesi öğrencilerinin öğretmenlik mesleğine yönelik tutumlarının 
karşılaştırılması. Erzincan Üniversitesi Eğitim Fakültesi Dergisi, 17(1), 307-324. https://doi.org/10.17556/jef.52416

Baykara Pehlivan, K. (2008). Sınıf öğretmeni adaylarının sosyo-kültürel özellikleri ve öğretmenlik mesleğine yönelik tutumları üzerine bir çalışma. Mersin Üniversitesi Eğitim Fakültesi Dergisi, 4(2), 151-168.

Bhargava, A., and Pathy, M. (2014). Attitude of student teachers towards teaching profession. Turkish Online Journal of Distance Education, 15(3), 27-36. https:/ / doi.org/10.17718/tojde.15072

Bilgiç, H. F. (2017). Örgütsel bağlılık-iş tatmini ilişkisi. Bitlis Eren Üniversitesi İktisadi ve İdari Bilimler Fakültesi Akademik İzdüşüm Dergisi, 2(3), 35-49.

Bilgin, H. (1996). Okul öncesi eğitim kurumlarında çalışan öğretmenlerin öğretmenlik tutumlarının incelenmesi. (Yayımlanmamış yüksek lisans tezi). Marmara Üniversitesi, İstanbul.

Brown, H. D. (2001). Teaching by principles: An interactive approach to language pedagogy San Francisco, CA: Longman.

Büyüköztürk, Ş. (2011). Sosyal bilimler için veri analizi el kitabı. Ankara: Pegem Akademi Yayıncılık.

Camadan, F., ve Duysak, A. (2010). Farklı programlardaki öğretmen adaylarının öğretmenlik mesleğine yönelik tutumlarının çeşitli değişkenler açısından karşılaştırılması: Rize Üniversitesi örneği. Sakarya Üniversitesi Eğitim Fakültesi Dergisi, 20, 30-42.

Chan, F., Cheing, G., Chan, J. Y. C., Rosenthal, D. A., and Chronister, J. (2006). Predicting employment outcomes of rehabilitation clients with orthopedic disabilities: A CHAID analysis. Disability and Rehabilitation, 28(5), 257-270. https:/ / doi.org/10.1080/09638280500158307

Chan, W. Y., Lau, S., Lim, S., and Hogan,. (2008).Organizational and personal predictors of teacher commitment: The mediating role of teacher efficacy and identification with school. American Educational Research Journal, 45(3), 597-630. https:/ / doi.org/10.3102/0002831208318259

Çeliköz, N., ve Çetin, F. (2004). Anadolu öğretmen lisesi öğrencilerinin öğretmenlik mesleğine yönelik tutumlarını etkileyen etmenler. Milli Eğitim Dergisi, 162(1), 139-157.

Çetin, Ş. (2003). Anadolu öğretmen lisesi ve düz (genel) lise çıkışlı eğitim fakültesi öğrencilerinin öğretmenlik mesleğine yönelik tutumlarının karşılaştırılması. (Yayımlanmamış Doktora Tezi). Gazi Üniversitesi, Ankara.

Dashputra, A. V., Chari, S., Badwaik, R. T., and Sidddique, R. (2019). Medical teachers' attitude towards teaching profession. National Journal of Integrated Research in Medicine, 10 (1), 11-16.

Doğan, S. (2013). Sını öğretmenlerinin öz yeterlik algısı ve öğretmenlik mesleğine yönelik tutumlarının incelenmesi (A ğr ili örneği ). (Yayımlanmamış Yüksek Lisans Tezi). Erzincan Üniversitesi, Erzincan.

Dokumacı Sütçü, N., ve Oral, B. (2019). Ortaokul ve lise öğrencilerinin öğretmenlere yönelik güven alg1ları. Electronic Journal of Social Sciences, 18(71), 1120-1134. https:/ / doi.org/10.17755/esosder.466793 
Durmuşoğlu, M. C., Yanık, C., ve Akkoyunlu, B. (2009). Türk ve Azeri öğretmen adaylarının öğretmenlik mesleğine yönelik tutumları. Hacettepe Üniversitesi Eğitim Fakültesi Dergisi, 36 (36), 76-86.

Duygulu, S., ve Abaan, S. (2007). Örgütsel bağlılık: Çalışanların kurumda kalma ya da kurumdan ayrılma kararının bir belirleyicisi. Hacettepe Üniversitesi Hemşirelik Fakültesi Dergisi, 14(2), 61-73.

Ekici, E. (2012). Farklı sınıflandırma yöntemlerinin karşılaştırılması ve bir uygulama. (Yayımlanmamış Yüksek Lisans Tezi). Fırat Üniversitesi, Elazı̆̆.

Elina, S. (2016). Attitude of teachers towards teaching profession. Quest Journals; Journal of Research in Humanities and Social Science. 4(6), 103-105.

Eraslan, L., ve Çakıcı, D. (2011). Pedagojik formasyon programı öğrencilerinin öğretmenlik mesleğine yönelik tutumları. Kastamonu eğitim dergisi, 19(2), 427438.

Erden, M. (1995). Öğretmen adaylarının öğretmenlik sertifikası derslerine yönelik tutumları. Hacettepe Üniversitesi Eğitim Fakültesi Dergisi, 11(11), 99-104.

Erkuş, A., Sanlı, N., Bağlı, M. T., and Güven, K. (2000). Öğretmenliğe ilişkin tutum ölçeği geliştirilmesi. Eğitim ve Bilim, 25 (116), 27-33.

Gül, H. (2002). Örgütsel bağlılık yaklaşımlarının mukayesesi ve değerlendirmesi. Ege Akademik Bakış Dergisi, 2(1), 37-56.

Güloğlu Demir, C. (2016). Sınıföğretmenlerinin mesleki görevlerine yönelik ders dışı zaman kullanımları ve öğretmenlik mesleğine yönelik tutumlarının belirlenmesi. Yayınlanmamış doktora tezi, Gazi Üniversitesi, Ankara.

Gürsoy, R. C. (2009). Okul öncesi öğretmenlerinin benlik saygılarının öğretmenlik tutumlarma etkisinin incelenmesi. Yayınlanmamış yüksek lisans tezi, Marmara Üniversitesi, İstanbul.

Karakaya, Y. E., ve Karademir, T. (2013). Beden eğitimi öğretmenlerinin örgütsel bağlılık düzeyleri. Spor Bilimleri Dergisi, 24(1), 37-44.

Karasar, N. (2011). Bilimsel araştırma yöntemi (22. Bask1). Ankara: Nobel Yayın Dağıtım.

Karataş, S., ve Güleş, H. (2010). İlköğretim okulu öğretmenlerinin iş tatmini ile örgütsel bağlılığı arasındaki ilişki. Uşak Üniversitesi Sosyal Bilimler Dergisi, 3(2), 74-89. https:/ / doi.org/10.12780/UUSBD73

Kayri M. (2007), Araştırmalarda iki aşamalı kümeleme analizi ve bir uygulaması, Eurasian Journal of Educational Research, 28, 89-99.

Kayri, M., and Boysan, M. (2007). Using chaid analysis in researches and an application pertaining to coping strategies. Ankara University, Journal of Faculty of Educational Sciences, 40(2), 133-149.

Kayri, M., Elkonca, F., Şevgin, H., ve Ceyhan, G. (2014). Ortaokul öğrencilerinin fen ve teknoloji dersine yönelik tutumlarının CHAID analizi ile incelenmesi. Ĕğitim Bilimleri Araştırmaları Dergisi, 4(1), 301-316. https:/ / doi.org/10.12973/jesr.2014.41.15

Kaysi, A. G. F., ve Gürol, A. (2016). Öğretmenlik mesleğine yönelik öğretmen görüşlerinin değerlendirilmesi. Eğitim ve Öğretim Araştırmalarn Dergisi, 5(2), 230 240. 
Kılıç, G. (2008). Kariyer yönetimi ve örgütsel bağhlık arasındaki ilişki: Beş yıldızlı otel işletmelerde bir araştırma. (Yayımlanmamış Doktora Tezi) Gazi Üniversitesi, Ankara.

Korkmaz, G., ve Sadık, F. (2011). İlköğretim okullarında görev yapan öğretmenlerin mesleki tutumlarının sosyo demografik özellikler açısından incelenmesi. Çukurova Üniversitesi Sosyal Bilimler Enstitüsü Dergisi, 20(1), 121138.

Kumar, R. V. (2017). Attitude of postgraduate students towards the teaching profession. MIER Journal of Educational Studies, Trends and Practices, 6(2), 193203.

Kültekin, S. (2006). Bilgi toplumu ve eğitim programları. (Yayımlanmamış Yüksek Lisans Tezi). Balıkesir Üniversitesi, Balıkesir.

Milanović, M., and Stamenković, M. (2016). CHAID decision tree: Methodological frame and application. Economic Themes, 54(4), 563-586.

https:/ / doi.org/10.1515/ethemes-2016-0029

Nagar, K. (2012). Organizational commitment and job satisfaction among teachers during times of burnout. Vikalpa, 37(2), 43-60. https:/ / doi.org/10.1177/0256090920120205

Odike, M. N., and Nnaekwe, K. (2018). Influence of teachers' attitude towards teaching profession on under graduate non-education students perception of teacher education. International Journal of Academic Research in Progressive Education and Development, 7(4), 67-79. https:/ / doi.org/10.6007/IJARPED/v7i4/ 4833

Oral, B. (2004). Eğitim fakültesi öğrencilerinin öğretmenlik mesleğine ilişkin tutumlar1. Eurasian Journal of Educational Research, 15, 88-98.

Oral, B., Dokumacı Sütçü, N., ve Yazar, T. (2019). Türkiye'de öğretmenlik mesleğine yönelik tutum ile ilgili yapılan makalelerin incelenmesi. Türkiye Sosyal Araştırmalar Dergisi, 23, 41-56.

Özkan, H. H. (2012). Öğretmenlik formasyon programındaki öğretmen adaylarının öğretmenlik mesleğine ilişkin tutumlarının incelenmesi (SDÜ Örneği). Ahi Evran Üniversitesi Kırşehir Ĕ̆itim Fakültesi Dergisi, 13(2), 29-48.

Özoğlu, M. (2010). Türkiye' de öğretmen yetiştirme sisteminin sorunları. SETA Analiz, 137.Erişimadresi:https://www.academia.edu/1358721/T\%C3\%Bcrkiyede_\% C3\%96\%C4\%9Fretmen_Yeti\%C5\%9Ftirme_Sisteminin_Sorunlar\%C4\%B1(Erişi mTarihi:26/05/2020)

Özyürek, A., ve Erbay, F. (2015). Okul öncesi öğretmenlerinin öğretmenlik tutumları ile yaşam doyumları arasındaki ilişkinin incelenmesi. Çankırı Karatekin Üniversitesi Sosyal Bilimler Enstitüsü Dergisi, 6(2), 31-48.

Pancholi, A., and Bharwad, A. B. J. (2015). Student-teachers' attitude towards teaching profession. International Journal of Research in Humanities and Social Sciences, 3(8), 40-43.

Pehlivan, G. (2006). CHAID analizi ve bir uygulama. (Yayımlanmamış Yüksek Lisans Tezi). Yıldız Teknik Üniversitesi, İstanbul.

Piji Küçük D. (2012). Müzik öğretmenlerinin müzik öğretmenliği mesleğine yönelik tutumları. Dicle Üniversitesi Ziya Gökalp Eğitim Fakültesi Dergisi, 19, 151-161. 
Polat, S. (2013). Pedagojik formasyon sertifika programı ve eğitim fakültesi öğrencilerinin öğretmenlik mesleğine yönelik tutumlarının incelenmesi. Euluslararası eğitim araştırmaları dergisi, 4(2), 48-60.

Polat, S., Arslan, Y., ve Satıcı, A. (2016). Öğretmenlerin mesleki tutumları ile sınıf disiplin modeli tercihleri arasındaki ilişki. Gazi Üniversitesi Gazi Eğitim Fakültesi Dergisi, 36(3), 675-691.

Saks, K., Soosaar, R., and Ilves, H. (2016). The students' perceptions and attitudes to teaching profession, the case of Estonia. In 7th International Conferece on Education and Educational Psychology, Rhodes, Greece.

Semerci, N., ve Semerci, Ç. (2004). Türkiye' de öğretmenlik tutumları. Fırat Üniversitesi Sosyal Bilimler Dergisi, 14(1), 137-146.

Stiegelbauer, S. (1992). Why we want to be teachers: New teachers talk about their reasons for entering the profession. Annual Meeting of the American Educational Research Association, San Francisco, CA.

Şahin, C., ve Şahin, S. (2017). Öğretmen adaylarının öğretmenlik mesleğine yönelik tutumları, öz-yeterlik inançları ve öğrenciyi tanıma düzeyleri. Journal of Turkish Educational Sciences, 15(2).

Şata, M. (2015). Lise öğrencilerinin fizik dersi tutumlarının CHAID analizi ve lojistik regresyon analizi ile karşılaştırmalı olarak incelenmesi. (Yayımlanmamış yüksek lisans tezi). Gazi Üniversitesi, Ankara.

Tadesse, E. F. (2019). Teachers' organizational commitment at secondary school in Addis Ababa, Ethiopia. International Journal of Education and Research, 7(4), 55-68.

Temizkan, M. (2008). Türkçe öğretmeni adaylarının öğretmenlik mesleğine yönelik tutumları üzerine bir araştırma. Türk Ĕ̆itim Bilimleri Dergisi, 6(3), 461-486.

Turhan Türkkan, B. T., Uyar, M. Y., ve Yolcu, E. (2017). Pedagojik formasyon öğrencilerinin "pedagojik formasyon" kavramına yönelik metaforik algılarının incelenmesi. Kırşehir Ĕ̈itim Fakültesi Dergisi, 18(1), 41-60.

Üstüner, M. (2006). Öğretmenlik mesleğine yönelik tutum ölçeğinin geçerlik ve güvenirlik çalışması. Kuram ve Uygulamada Ĕ̆itim Yönetimi Dergisi, 12(1), 109127.

Yaman, E., Yaman, H., ve Eskicumalı, A. (2001). Öğretmenlik mesleğinin sosyoekonomik statüsü/bu mesleğin bir bayan mesleği haline dönüşmesi durumu ve eğitim fakültesi üzerine bir araştırma. Sakarya Üniversitesi Eğitim Fakültesi Dergisi, 2, 53-68.

Zarzolawmi, W. (2019). Attitude of secondary school teacher of aizawl district towards teaching profession. Unpublished master dissertation, University of Mizoram, Tanhril.

\section{Summary}

\section{Introduction}

Teachers are one of the most important elements of education systems. Therefore, the success of education systems is directly proportional to the qualifications and competencies of teachers. The qualifications of teachers play a key role in the realization of the programs and achieving the intended gains in education. These 
qualifications can be listed as the field knowledge, pedagogical formation knowledge, general culture and talent knowledge. In addition to these competencies, affective domain characteristics of teachers are also very important in order to be successful in the teaching profession. Attitudes are one of the characteristics discussed within the context of affective domain characteristics. Teachers' attitudes towards their profession are of great importance in fulfilling the requirements of the profession. Therefore, in this study, it was aimed to determine the independent variables that have a significant effect on the attitudes of teachers towards their profession and to reveal the order of importance of these variables.

\section{Method}

This is a relational (correlational) research since the relationship between the variables has been examined. The research was carried out with a total of 515 teachers working in Diyarbakır provincial center during the spring semester of the 2018-2019 academic year. "Personal Information Form" and "the Attitudes towards Teaching Profession Scale" were applied to the teachers who participated in the study. Descriptive statistics, Two-Stage Clustering Analysis and CHAID Analysis were used to analyse the data collected.

\section{Results}

As a result of the analysis, it was determined that $38.84 \%$ of the teachers have positive, $33.40 \%$ have moderate and $27.77 \%$ have negative attitudes with respect to the dimension of "love", which is one of the dimensions of the attitudes towards teaching profession; while $48.93 \%$ of the teachers have positive, $39.61 \%$ have moderate and $11.46 \%$ have negative attitudes with respect to the dimension of "satisfaction" and $54.37 \%$ of the teachers have positive, $34.37 \%$ have moderate and $11.26 \%$ have negative attitudes with respect to the dimension of "value", respectively. The predictor variable with the highest effect on the dimensions of love, satisfaction and value was found to be "the level of attachment felt towards the institution". Other predictive variables with a significant effect on the dimension of love are "whether they are satisfied with the salary", "gender", "socioeconomic levels of schools"; the other predictive variables that have a significant effect on the dimension of satisfaction are "seniority", "whether they are satisfied with the salary", "educational background", "gender"; and the other predictive variables that have a significant effect on the dimension of value are "socioeconomic levels of schools", "gender" and "educational background".

\section{Discussion}

The majority of the teachers have a positive attitude towards the love, satisfaction and value sub-dimensions of the attitudes towards teaching profession scale. The independent variable with the highest effect on the love, satisfaction and value dimensions is "the level of attachment felt towards the institution". The majority of the teachers are either highly or moderately attached to their institutions they are working for. Teachers, who are highly attached to their institutions, have a more positive attitude compared to those who have a low level of attachment. The variable that best describes the cluster of teachers, who are less or not attached to their institutions, in all three dimensions is "gender". In general, female teachers who have little or no attachment to their institutions have a more positive attitude compared to male 
teachers. The variable that best describes the cluster of teachers, who are moderately attached to the institution they work for, with respect to the dimension of love is "whether they are satisfied with the salary". The majority of the teachers, who are moderately attached to their institutions, do not find the salary they receive sufficient. Furthermore, among the teachers, who are moderately attached to the institution they work for, teachers who find the salary they receive sufficient have a more positive attitude towards the love dimension of the scale compared to those who do find the salary they receive insufficient. The variable that best describes the cluster of teachers, who are moderately attached to the institution they work for, with respect to the dimensions of value is "socioeconomic levels of their schools". The majority of the teachers, who are moderately attached to their institutions, state that they work in schools with either moderate or low socioeconomic level, while a few of them state that that they work in schools with high socioeconomic level. Among the teachers, who are moderately attached to their institutions, teachers stating that they work in schools with high socioeconomic level have a more positive attitude compared to those stating that they work in schools with moderate or low socioeconomic level. The variable that best describes the cluster of teachers, who are very attached to the institution they work for, with respect to the satisfaction dimension is "seniority". Among teachers, who are very attached to their institutions, teachers who have 1-5, 6-10, 21 and above seniority have a more positive attitude compared to those who have 11-15 and 16-20 seniority. The variable that best describes the cluster of teachers, who are very attached to the institution they work for, with respect to the value dimension is "educational background". Among teachers, who are very attached to their institutions, teachers with undergraduate, master's with thesis or doctoral degrees have a more positive attitude with respect to the value dimension compared to those holding a master's degree with no thesis.

\section{Pedagogical Implications}

An important result of the study is that the commitment of teachers to their institution affects their professional attitudes. Especially administrators in the institution have a duty to improve teachers' commitment to the institution they work for. In this regard, cultural and sports activities should be organized that will improve the teachermanager relationship positively and participation in these activities can be encouraged. Teachers' opinions can be taken into consideration in the decisions to be taken about the school in order to ensure their active participation. It can also be ensured that administrators do not put pressure on teachers and avoid unnecessary supervision. A functional working environment can be created to meet the needs of teachers. In addition, another important result of the research is that teachers' professional attitudes are affected by their salaries. Therefore, an income level that will satisfy teachers and raise their living standards can be provided.

\section{Araştırmanın Etik İzinleri}

Yapılan bu çalışmada "Yükseköğretim Kurumları Bilimsel Araştırma ve Yayın Etiği Yönergesi" kapsamında uyulması belirtilen tüm kurallara uyulmuştur. Yönergenin ikinci bölümü olan “Bilimsel Araştırma ve Yayın Etiğine Aykırı Eylemler” başlı̆̆ı altında belirtilen eylemlerden hiçbiri gerçekleştirilmemiştir.

Etik kurul izin bilgileri 
Etik değerlendirmeyi yapan kurul adı = Dicle Üniversitesi Rektörlüğü Eğitim Bilimleri Etik Kurulu

Etik değerlendirme kararının tarihi $=28 / 01 / 2019$

Etik değerlendirme belgesi sayı numarası $=90871155-044-$

\section{Authors' Biodata/ Yazar Bilgileri}

Neşe DOKUMACI SÜTÇÜ Dicle Üniversitesi Ziya Gökalp Eğitim Fakültesi Matematik ve Fen Bilimleri Eğitimi Bölümünde araştırma görevlisi olarak görev yapmaktadir.

Neşe Dokumacı Sütçü is a research assistant at Dicle University, Ziya Gökalp Faculty of Education, Department of Mathematics and Science Education.

Behçet ORAL Dicle Üniversitesi Ziya Gökalp Eğitim Fakültesi Eğitim Bilimleri Bölümünde öğretim üyesi olarak görev yapmaktadır.

Behçet Oral is a faculty member at Dicle University, Ziya Gökalp Faculty of Education, Department of Educational Sciences. 